\title{
The Flypaper Effect Unstuck: Evidence on Endogenous Grants from The Federal Highway Aid Program
}

\author{
Brian Knight \\ Division of Research and Statistics \\ Board of Governors of the Federal Reserve System \\ Washington, DC 20551 \\ brian.g.knight@frb.gov
}

September 11, 2000

\begin{abstract}
Contrary to simple theoretical predictions, empirical research has found that state government public spending is increased far more, often dollar-for-dollar, by federal grant receipts than by equivalent increases in constituent private income. This anomaly has come to be known as the flypaper effect. This paper provides a theoretical explanation for the flypaper effect, and empirically corroborates that explanation using data from the Federal Highway Aid Program. First, a legislative bargaining model demonstrates a positive correlation between constituent preferences for public goods and intergovernmental grant receipts, and this correlation has likely biased the existing literature towards finding a flypaper effect. Second, using measures of the political power of state congressional delegations as instruments for federal highway grants, as suggested by the bargaining model, grants receipts and constituent private income are found to have similar effects on public spending.
\end{abstract}

Thanks to Stephen Coate, Bob Haveman, Arik Levinson, Andy Reschovsky, Karl Scholz, and Donald Wittman for helpful insights. Thanks also to Julie D'Ambruoso for research assistance. The Christensen Award in Empirical Economics provided financial support.

The views presented are solely those of the author and do not necessarily represent those of the Federal Reserve Board or its staff. 


\title{
The Flypaper Effect Unstuck: Evidence on Endogenous Grants from The Federal Highway Aid Program
}

\author{
"Angels in heaven don't decide where highways will be built. This is a political process." \\ -- U.S. House Transportation Committee Chair Bud Shuster, defending the \\ earmarking of federal transportation aid for special highway projects. ${ }^{1}$
}

\section{Introduction}

Intergovernmental grants are fiscal transfers from higher-level to lower-level governments in a federal system. In the United States, grants received by state and local governments during fiscal year 1996 totaled $\$ 478$ billion, representing 6\% of GDP and 17\% of federal, state, and local combined public spending. ${ }^{2}$

In a simple fiscal policy model, Bradford and Oates (1971a, 1971b) demonstrate that intergovernmental grants to local governments are equivalent to cash payments to local constituents. Their model thus predicts that intergovernmental grant receipts and increases in local private income should identically affect local public spending. Empirical research, by contrast, has found that intergovernmental grants are disproportionately spent on public services and many studies have found that grant receipts increase public spending dollar-for-dollar. This anomaly has come to be known as the flypaper effect since money sticks where it hits. Private income is disproportionately spent on private consumption while a federal grant, income received by the public sector, is primarily spent on public services.

In this paper, I argue that this strong empirical relationship between intergovernmental grants and government spending has been misinterpreted due to the endogeneity of these grants. Federal legislators, elected to represent their jurisdictions,

\footnotetext{
1 The Washington Post, April 1, 1998.

2 Census Bureau's Survey of Governments and Economic Report of the President, 1999.
} 
typically bargain over the distribution of federal grants. Grant levels, the outcome of this bargaining process, likely reflect the underlying preferences of the residents of these jurisdictions. A legislative bargaining model developed in this paper predicts that federal legislatures will provide larger grants to those states with stronger unobserved preferences for public services. As a consequence, OLS regressions of state expenditures on intergovernmental grants and private income are likely biased towards measuring the flypaper effect. This endogeneity explanation is related to Besley and Case (1994), who study policy endogeneity in the context of workers' compensation benefits. Since states set these benefits through a political process, the authors argue that difference-in-difference estimation provides biased economic incidence estimates. As an alternative, they suggest the use of political variables as instruments.

As an illustration of this grant endogeneity, consider the Big Dig, a highway project in Boston. In 1983, Governor Dukakis' administration conceived a plan to move underground the Central Artery, a deteriorating section of elevated highway, and Speaker of the U.S. House of Representatives Thomas (Tip) O’Neill (D, MA) secured federal funds for the project in 1985. Figure 1 depicts Massachusetts highway finances from 1983 forward. Between 1991 and 1998, when federal grants were growing most rapidly, Massachusetts spent $\$ 6$ billion on the Big Dig project, more than all other combined highway spending in the state. ${ }^{3}$ The strong correlation (0.94) between highway spending and grants in Massachusetts, depicted in Figure 1, has traditionally been interpreted in the literature as the flypaper effect. However, the increase in federal grants was not exogenous in this case. A third factor, the state's desire to complete a particular project, simultaneously increased both federal grants and highway spending. With only this variation in grants and spending, one cannot distinguish between the endogenous grants

3 The Boston Herald, October 13, 1998 
hypothesis, the conjecture that unobserved factors influence both grants and spending, and the flypaper effect hypothesis, the idea that grants significantly increase spending. ${ }^{4}$

Instrumental-variables estimators distinguish between the endogenous grants and flypaper effect hypotheses, which are both consistent with Figure 1, by separating federal grants into exogenous and endogenous components. Using the exogenous component, the estimator measures the true marginal propensity to consume public services from federal grants. As instruments for grant levels, a political economy model motivates measures based on the political power of state congressional delegations. Particular instruments include committee representation, the proportion of representatives in the majority party, and the average tenure of representatives. Using these political instruments, income and grants are found to have similar effects on public spending, suggesting an equivalence between these two resources and no flypaper effect.

\section{Flypaper Effect Estimates and Existing Explanations}

\section{Flypaper Effect Estimates}

To motivate a standard empirical specification in the flypaper effect literature, consider a simple model of a single state government allocating resources, private income and federal grants, between consumption of private and public goods. Consistent with the empirical literature, which typically assumes exogenous grant levels, this section treats these grants as predetermined. The next section relaxes this assumption by constructing a model in which federal and state officials simultaneously determine both federal grant levels and state public spending according to a political bargaining process.

\footnotetext{
${ }^{4}$ In the context of this example, there is a third possible explanation for the strong correlation between highway grants and spending. The equivalence prediction of Bradford and Oates applies only to small grant programs, those for which states would supplement grant receipts with own tax revenue. Given the generous federal funding provided for the Big Dig project, Massachusetts may choose not to supplement this funding with tax revenue. In this case, the strong correlation may simply reflect a binding constraint for spending on this large project.
} 
A single state has $\mathrm{N}$ identical residents, each with Stone-Geary utility over a public $\operatorname{good}(\mathrm{G})$ and a private $\operatorname{good}\left(\mathrm{c}_{\mathrm{i}}\right)$ :

$$
\mathrm{U}\left(\mathrm{G}, \mathrm{c}_{\mathrm{i}}\right)=\beta \ln (\mathrm{G}-\mu)+(1-\beta) \ln \left(\mathrm{c}_{\mathrm{i}}\right)
$$

where $\mu$ is the Stone-Geary minimum consumption parameter. ${ }^{5}$ The public good is financed through a combination of lump-sum state taxes $(\tau)$ and federal grants-in-aid (A), which are given exogenously. Thus, the state government faces a public-sector resource constraint:

$$
P G=\tau \mathrm{N}+\mathrm{A}
$$

where $\mathrm{P}$ is price of public goods, relative to private goods. ${ }^{6}$

Each individual faces a private budget constraint:

$$
c_{i}=m-\tau
$$

where $\mathrm{m}$ is individual private income.

Substituting (3) into (2) yields a combined resource constraint:

$$
\mathrm{PG}+\mathrm{Nc}_{\mathrm{i}}=\mathrm{A}+\mathrm{M}
$$

where $\mathrm{M}=\mathrm{Nm}$ is community income.

Since the federal government earmarks these grants for public purposes, public spending must exceed the grant level $(P G \geq A)$. Assuming an interior solution $(P G>A)$, maximization of (1) subject to (4) yields a state government expenditure function:

$$
\operatorname{EXPEND}=\mathrm{PG}^{*}=\beta \mathrm{A}+\beta \mathrm{M}+(1-\beta) \mathrm{P} \mu
$$

Thus, this model predicts an equivalence between private income and grants. The marginal propensity to consume (MPC) public goods from federal grants should equal that from private income:

$$
\partial \mathrm{EXPEND} / \partial \mathrm{A}=\partial \mathrm{EXPEND} / \partial \mathrm{M}=\beta
$$

\footnotetext{
${ }^{5}$ Cobb-Douglas utility generates an expenditure function linear in income and grants, a commonly used empirical specification. Stone-Geary utility, a generalization of Cobb-Douglas, allows for heterogeneity across states in preferences for the public good through the minimum consumption parameter, $\mu$.

${ }^{6}$ Of course, governments produce, rather than purchase, public services. In this case, $\mathrm{P}$ can be interpreted as the slope of a linear production possibilities frontier for public and private goods.
} 
If the distribution of federal grants is independent of preferences for public services, as is often used implicitly assumed in this empirical literature, one could treat the remainder term $(1-\beta) \mathrm{P} \mu$ in equation (5) as unobserved, random heterogeneity across states. In this case, an OLS regression of federal grants and private income on public spending will produce unbiased and consistent estimates of the marginal propensities to consume $(\beta)$ in equation 5. A comparison of the coefficients on income and grants from this regression provides a statistical test of the theoretical prediction of equal MPCs from income and grants.

Previous empirical studies, summarized in Table 1, have regressed public spending on grants and private income, often with additional control variables, and reject this theoretical prediction of equal MPCs. According to these results, the marginal propensity to consume public services from grants far exceeds that from income. Although these 14 studies examine different grant programs, study different years, and employ different covariates, all find that grants stimulate far more public spending than do increases in the private income of constituents. This result, a non-equivalence between grants and income, has been interpreted as the flypaper effect. Many of these estimates find a MPC from income close to zero and an MPC from grants close to one, implying that all grants are spent on public goods and that increases in private income are spent entirely on private goods.

\section{Existing explanations}

Since researchers uncovered this anomaly, the literature has taken two paths. ${ }^{7}$ First, some theoretical research has attempted to provide economic and political

\footnotetext{
7 The reviews of Gramlich (1977), Oates (1994), Hines and Thaler (1995), and Bailey and Connolly (1998) provide more complete survey of explanations for the flypaper effect.
} 
explanations for this empirical finding. The most prominent paper in this branch is Filimon, Romer, and Rosenthal (1982), who apply the agenda setter model of Romer and Rosenthal (1978, 1979b) to study the flypaper effect. Their fiscal illusion model challenges Bradford and Oates' assumptions of complete voter information and a political system that is responsive to constituent preferences. Budget-maximizing public officials, who are not subject to electoral competition, increase public spending by the entire grant amount if voters do not have sufficient information. Using evidence from Oregon school districts, they find that fiscal illusion, through the flypaper effect, increased education spending in these districts approximately dollar-for-dollar. Note that this fiscal illusion prediction, a marginal propensity to consume public services from grant receipts of one, is associated with a more restrictive flypaper effect definition. For the remainder of the paper, I will refer to this more restrictive definition as the dollar-for-dollar flypaper effect and the less restrictive definition as simply the flypaper effect.

The second path of research has defended the equivalence prediction of Bradford and Oates and focuses on possible errors in the econometric analysis of the studies in Table 1. Moffit (1984) argues that previous research on intergovernmental grants has ignored the importance of price effects inherent in open-ended matching grant programs. Accounting for the kinked nature of state budget constraints and associated price effects in the AFDC matching grant program, Moffit finds that the flypaper effects disappears, and he argues that previous estimates of the flypaper effect may be caused by these price effects. While providing a compelling account of the flypaper effect in matching grant programs, this correction does not explain the presence of the flypaper effect found in lump-sum grant programs. $^{8}$ Related to this explanation is Chernick $(1979,1981)$, who argues that federal agencies may award project grants to those communities that are willing to commit

\footnotetext{
${ }^{8}$ For an example, see Inman (1971).
} 
relatively more of their own revenues to the project. This targeting serves to convert lumpsum grant programs into grant programs with implicit matching provisions. As empirical support for this argument, he finds a positive correlation between grant levels and proposed contributions of own revenues in the HUD Water and Sewer program. However, he makes no attempt to correct empirically for this targeting in a traditional equivalence test specification.

In an alternative explanation focusing on econometric errors, Hamilton (1983) argues that the flypaper effect may be due to omitted variable bias if private income is correlated with public good production costs. For example, jurisdictions with higher incomes may need to spend less than low income jurisdictions in order to provide a given level of educational achievement due to unobserved costs. He argues that the presence of these unobserved cost factors biases downward the income coefficient. ${ }^{9}$ While demonstrating this argument theoretically, he does not attempt to correct empirically for this omitted variable bias.

As another explanation focusing on omitted variable bias, a few recent studies have recognized the possibility of grant endogeneity. Although this endogeneity is not their main focus, these studies use instrumental variable techniques in some of their specifications. Becker (1996), in a study of functional form assumptions in the flypaper effect literature, uses state demographic instruments and finds a diminished flypaper effect. Gamkhar and Oates (1996), study state responses to grant increases, relative to grant decreases, and find no evidence of asymmetries. In this study, they use national aggregate time-series variation in demographics as instruments but still find evidence of the flypaper effect. Since federal grants are often distributed by formulas relating to state characteristics,

\footnotetext{
${ }^{9}$ Given his focus on heterogeneity in income across jurisdictions, Hamilton does not address the possibility of a correlation between unobserved costs and grant levels.
} 
these demographics are correlated with grant levels, the first requirement for an instrument to be valid. However, demographics may be invalid instruments if these measures represent states' preferences for public services. ${ }^{10}$

\section{A Model with Endogenous Grants}

\section{Theoretical Framework}

The simple theoretical model of the previous section, as well as the empirical estimates of the flypaper effect in Table 1, rely on the assumption that grants are exogenous to states' public spending decisions. However, federal legislatures, composed of representatives from these states, typically bargain over the distribution of grants across states. Grant levels, the outcome of this process, may thus reflect unobserved characteristics of these states and the preferences of their constituents.

As a representation of this bargaining process, consider a federation of $\mathrm{S}$ states. Each state has the preferences and resources in the single state model of the previous section. Across states, residents vary in their preference for the public good. That is, states have residents with either low or high preferences for public services; this heterogeneity is reflected in the Stone-Geary minimum consumption parameter $\left(\mu_{\mathrm{s}} \in\left\{\mu_{\mathrm{L}}, \mu_{\mathrm{H}}\right\}\right)$. To simplify the analysis, all other attributes are assumed homogenous across states.

The bargaining model consists of two stages, a federal budgetary stage and a state budgetary stage. In the first stage, a federal legislature, with one representative from each state, determines the distribution of grants across states from a federal budget of size B, which is given exogenously. The second stage is essentially the single state model of the

\footnotetext{
10 In addition to demographics, Gamkhar and Oates use partisan control of the U.S. Congress as an instrument for grant levels. Unfortunately, this measure may also reflect time-series variation in preferences for public services through the choice of voters.
} 
previous section, in which state governments, taking first-stage intergovernmental grant levels as given, allocate grants and private income between public and private consumption.

1. Federal budgetary stage:

a) The committee chair, exogenously assigned to one representative, proposes a distribution of grants-in-aid $\left(\mathrm{A}_{1}, \mathrm{~A}_{2}, \ldots, \mathrm{A}_{\mathrm{S}}\right)$ from the total federal budget of size $\mathrm{B}$. No amendments are permitted to this proposal. ${ }^{11}$

b) All representatives vote on this proposal. If a majority approves it, this proposed federal budget is implemented and financed with individual lump-sum federal taxes $\tau_{\mathrm{f}}=\mathrm{B} /(\mathrm{SN})$. If a majority does not approve it, no grants are provided $\left(\tau_{\mathrm{f}}=0\right.$ and $\mathrm{A}_{\mathrm{s}}=0$, all $\mathrm{s}$ ).

2. State budgetary stage: each state government, given the preferences in equation (1) and the resource constraint in equation (4) from the previous section, chooses a level of public spending at least as large as federal grants $\left(\operatorname{EXPEND}_{\mathrm{s}} \geq \mathrm{A}_{\mathrm{s}}\right)$.

To understand the equilibrium of this model, first note that a representative will always vote against a federal budget that provides his home state a federal grant, which is earmarked for public spending, that is less than their total federal tax contribution of B/S. If the federal budget does not pass, total disposable income will be higher by B/S and private income, relative to federal grants, is more valuable to states since it can be spent on either public or private goods. Thus, the chair must provide a grant of at least B/S to secure a state's vote. For states that would spend more on public services than a grant

\footnotetext{
${ }^{11}$ Highway aid authorization bills are typically considered under a closed rule, which prohibits amendments to the committee's version of the bill (Evans, 1994).
} 
equal to their federal tax contribution, this grant level of $\mathrm{B} / \mathrm{S}$ is sufficient to secure their vote.

Since the chair requires only a majority of votes to pass his proposed federal budget, he will provide positive grants to a minimum winning coalition of $(\mathrm{S}+1) / 2$ states, including his home state, and will provide no grants to the remaining states. To maximize the grant for his home state, the chair will include in this coalition those states whose votes can be secured with the least possible outlay. That is, this coalition will consist of those states whose votes are the least costly to secure.

In this model, the votes of high-spending states are cheaper to secure, relative to low-spending states, assuming that the federal budget size (B) is sufficiently large. This budget must be large enough that low-spending states do not supplement, with state taxes, a grant that is equal to their federal tax contribution. ${ }^{12,13}$ Low-spending states require higher grant levels since their federal tax contribution is returned in the form of a grant earmarked for public services, a good for which they have only a weak preference.

Figures 2 and 3 demonstrate these differential costs of securing votes from low and high-spending states ( $\mathrm{c}_{\mathrm{L}}$ and $\mathrm{c}_{\mathrm{H}}$, respectively). Note that these figures depict the minimum grant levels required to secure the respective vote and thus depict hypothetical, rather than equilibrium, grant payments. Consider first the cost of securing a vote for the case, depicted in Figure 2, in which the federal budget is small enough that high-spending states will choose to supplement, with state tax revenue, a federal grant equal to their federal tax

\footnotetext{
12 Since low-spending states will not supplement this grant, the chair must provide these states with more than their federal tax payment to compensate these states for returning their money with strings attached. If the federal budget size were not sufficiently large, the committee chair could secure the vote of a high or lowspending state with a grant equal to their federal tax contribution and would be indifferent between providing a grant to a high and a low-spending state.

13 The minimum budget size is given by the expression:

$\mathrm{B} \geq\left[\mathrm{NS} \beta \mathrm{M}+(1-\beta) \mathrm{NSP} \mu_{\mathrm{L}}\right] /[\mathrm{N}(1-\beta)+\beta]$

To derive this expression, use disposable income, $\mathrm{M}-\tau_{\mathrm{f}}$, in equation (5):

$\beta\left(M-\tau_{f}\right)+\beta A_{s}+(1-\beta) P \mu_{L} \leq A_{s}$. Next, use the fact that $\tau_{f}=B / S N$ and $A_{s}=B / S$ when the federal grant equals the state's federal tax contribution. Finally, solve for B.
} 
contribution. ${ }^{14}$ Community-wide private consumption is on the vertical axis and consumption of the public good is on the horizontal axis. The resource constraint connecting $\mathrm{M}$ and $\mathrm{M} / \mathrm{P}$ depicts the situation in which a majority votes against the federal budget and no federal grants are provided. The second resource constraint, starting at $\mathrm{M}-(\mathrm{B} / \mathrm{S})$ and with a kink at $\mathrm{c}_{\mathrm{H}} / \mathrm{P}=\mathrm{B} / \mathrm{SP}$ for high types and $\mathrm{c}_{\mathrm{L}} / \mathrm{P}$ for low types, corresponds to an approved federal budget with positive federal grants and taxes. The two indifference curves correspond to the preferences of the low and high-spending types. In this case, the high-demand representative will be indifferent between a federal budget with a grant equal to their federal tax contribution (B/S) and a federal budget with no grants. Thus, to secure the vote of high-spending states, the committee chair can offer them a grant equal to their federal tax contribution $\left(\mathrm{c}_{\mathrm{H}}=\mathrm{B} / \mathrm{S}\right)$. In order to secure the vote of low-spending representatives, the committee chair would need to offer a grant higher than the federal tax contribution ( $\left.\mathrm{c}_{\mathrm{L}}>\mathrm{B} / \mathrm{S}\right)$. Thus, the vote of the high-spending state is cheaper for the chair to secure.

Consider next the differential costs, depicted in Figure 3, for the case in which the federal budget size is large enough that high-spending states will not supplement, with state revenue, a federal grant equal to their federal tax contribution. ${ }^{15}$ As in figure 2 , the vote of high-spending states is cheaper than that of the low-spending state $\left(\mathrm{c}_{\mathrm{H}}<\mathrm{c}_{\mathrm{L}}\right) .{ }^{16}$

In both figures, the committee chair must offer a higher grant level to low-spending states as compensation for returning their federal tax contribution as a grant earmarked for public services, a good for which they have a weak preference. Thus, in equilibrium, the

\footnotetext{
${ }^{14} \mathrm{~B}<\left[\mathrm{NS} \beta \mathrm{M}+(1-\beta) \mathrm{NSP} \mu_{\mathrm{H}}\right] /[\mathrm{N}(1-\beta)+\beta]$.

$15 \mathrm{~B} \geq\left[\mathrm{NS} \beta \mathrm{M}+(1-\beta) \mathrm{NSP} \mu_{\mathrm{H}}\right] /[\mathrm{N}(1-\beta)+\beta]$.

16 This result in Figure 3 depends upon a single-crossing property. Stone-Geary, as well as other utility functions, exhibits this single-crossing property.
} 
chair will provide grants to as many high-spending states as possible because securing their vote is less costly, relative to the vote of low-spending states. ${ }^{17,18}$

In taking legislator preferences as given, this model provides only a partial account of the political process. Two recent papers, Chari, Jones, and Marimon (1997) and Besley and Coate (1997), have studied the interactions between elections to legislatures and legislative bargaining. ${ }^{19}$ In both of these models, districts have an incentive to strategically delegate to high-spending representatives in order to increase centralized provision of local public goods for their districts. Applying this logic to the model with endogenous grants, low-spending states may have an incentive to delegate bargaining representation to highspending constituents. In this case, low and high-spending states would be equally likely to be included in the winning coalition. However, federal legislatures set many different policies in addition to determining federal highway grants, the empirical application of this paper. This multidimensional nature of policies makes it more difficult for states to delegate strategically to a single representative across all policy dimensions. For example, if federal legislatures provide national public goods, in addition to federal grants, the incentives to delegate to high-spending representatives will be diminished since the

\footnotetext{
17 If there are not $(\mathrm{S}-1) / 2$ high-spending states, the committee chair will include some low-spending states until the coalition size is $(\mathrm{S}+1) / 2$, including the committee chair.

18 Although this model delivers a stark prediction of a no grants for those states outside of the winning coalition, the result can be interpreted more generally as creating a distribution of grants, in which some states receive high grant levels and others receive low grant levels. Both the universalistic and Coasian bargaining models predict positive grant levels for all states as well as a positive correlation between grants and preferences for public goods. The universalistic bargaining model of Weingast, Shepsle, and Johnsen (1981) predicts that each legislator will receive his most preferred spending level. Thus, legislators from states with stronger preferences for public services will demand more for their district. Wittman (1989) argues that Coasian bargaining will produce an efficient distribution of local public goods. In this case, jurisdictions with stronger preferences for public services again receive larger grants.

${ }_{19}$ Chari, Jones, and Marimon (1997) provide an explanation for the prevalence of split-ticket voting in legislative and executive elections. Besley and Coate (1999) apply the citizen candidate model of Besley and Coate (1997) to re-examine Oates' (1972) Decentralization Theorem from a political economy perspective.
} 
influence of this high-spending representative may increase the national public good level above that preferred by constituents. ${ }^{20}$

\section{Empirical Implications}

Since high-spending states receive larger grants, on average, than do low-spending states in equilibrium, the correlation between preferences for the public good and grant levels is positive $\left(\rho_{\mu, A}>0\right)$. This correlation is derived in Appendix 1 , under the assumption that representatives from low and high-spending states are equally likely to be assigned to the committee chair.

The theoretical prediction of a positive correlation between grant levels and preferences for public goods has important implications for the empirical flypaper effect literature. Consider the probability limit of the coefficients of an OLS regression of state public expenditures on grants $\left(\mathrm{b}_{\mathrm{A}}\right)$ and income $\left(\mathrm{b}_{\mathrm{M}}\right)$ :

$$
\begin{aligned}
& \operatorname{plim}\left(\mathrm{b}_{\mathrm{A}}\right)=\beta+(1-\beta) \mathrm{P}\left(\sigma_{\mu} / \sigma_{\mathrm{A}}\right) \rho_{\mathrm{A}, \mu} \\
& \operatorname{plim}\left(\mathrm{b}_{\mathrm{M}}\right)=\beta
\end{aligned}
$$

These expressions are derived in Appendix 2 using equation 5 and assumptions of exogenous income $\left(\rho_{\mu, M}=0\right)$ and non-redistributive grants $\left(\rho_{A, M}=0\right) .{ }^{21}$ Thus, the magnitude of the flypaper effect, a rejection of the equivalence prediction, depends upon the private consumption budget share $(1-\beta)$, the price of public relative to private goods $(P)$, the variation in unobserved preferences relative to the variation in grants $\left(\sigma_{\mu} / \sigma_{\mathrm{A}}\right)$, and the correlation between grant receipts and unobserved preferences $\left(\rho_{\mu, A}\right)$. Given that these first

\footnotetext{
20 Chari, Jones, and Marimon (1997) argue that consideration of a national policy, which they label foreign policy, does not alter states' incentives to elect high-spending representatives. However, their result rests on the assumption of a legislature with a large number of districts. In this case, each representative has only a small influence on national policies. In addition, their model includes a president who serves to constrain the legislature from adopting extreme national policies.

${ }^{21}$ Income is typically taken as exogenous in political economy models. The empirical results below, which yield only a weak correlation between income and grants, support the non-redistributive grants assumption.
} 
three terms are positive by definition, the limit of the grants coefficient exceeds the limit of the income coefficient due to the theoretical prediction of a positive correlation between grant levels and preferences for public spending.

This empirical implication of grant endogeneity can also be represented graphically. Figure 4 depicts both the true and estimated grant expansion paths. The true grant expansion path represents the relationship between consumption bundles and grant levels, for both high and low spending states $\left(\mathrm{GEP}_{\text {low }}\right.$ and $\left.\mathrm{GEP}_{\text {high }}\right)$. The estimated grant expansion path (GEPOLS) relies on cross-state variation; representative low-spending and highspending states receive equilibrium grant levels of zero and B/S, respectively, in this figure. This estimated grant expansion path incorrectly suggests a much stronger causal relationship between grants and public spending. One dollar in grants increases spending by more than one dollar since private consumption falls along the estimated grant expansion path. This interpretation is flawed in its comparison of public spending across states with unobserved preferences that are positively correlated with grant levels.

Thus, even in the context of this model, which predicts an equivalence between grants and private income, an OLS regression of spending on private income and grants will yield the flypaper effect, a larger coefficient on grants than income, due to the positive correlation between grant levels and unobserved preferences for public services. To correct empirically for this endogeneity of grants, the bargaining model suggests instruments for grants based upon cross-state variation in committee membership. In the model, the committee chair converts the federal tax contribution of low-spending states into an increased grant level for his home state. Therefore, this membership will be positively correlated with grant levels but should affect state spending only indirectly, through this higher grant level. More broadly, this membership can be interpreted as a measure of the 
political power of state delegations. Majority party affiliation and tenure of states' representatives serve as two additional measures of this political power.

\section{Federal Highway Aid Program}

To correct empirically for this grant endogeneity, this paper uses evidence from the Federal Highway Aid Program. The federal government levies a tax on gasoline sales, currently set at 18.4 cents per gallon. The proceeds of this federal tax are deposited into the Federal Highway Trust Fund and finance matching grants to state governments for highway construction and maintenance. States may use authorized funds for construction and improvement of roads that are designated federal-aid highways. Among statecontrolled roads, the federal-aid highway system supports $72 \%$ of total lane mileage and $85 \%$ of the total road miles traveled in the United States in $1997 .{ }^{22}$

Although highway grants are distributed primarily according to formula, individual legislators, especially those with political power, have available several means for altering the distribution of grants for the benefit of their home state. In reference to highway grants, Sen. Patrick Moynihan (D, NY) stated 'You don't have a formula here, you have 50 negotiated numbers." ${ }^{3}$ The first tool available to legislators is demonstration projects, commonly known as earmarks, which are typically identified by House and Senate transportation committees. The most recent reauthorization included 1,467 earmarks with a total cost of $\$ 9$ billion. Second, legislators can simply create new grant programs. During the 1992-1997 authorization negotiations, the Senate created a new formula for distributing a trust fund surplus. The new formula, proposed by Sen. Robert Byrd (D, WV), primarily provided benefits to those states, such as West Virginia, with high state gasoline

\footnotetext{
22 Highway Statistics, 1995 (tables HM-16 and VM-3)

23 Washington Post, May 23, 1998
} 
tax rates and low per-capita income. ${ }^{24}$ Third, legislators can change the Interstate Cost Estimate, a list of projects eligible for federal funds. In 1985, Thomas (Tip) O'Neil (D, MA) used his power as Speaker of the House to add the Big Dig project to this list, thereby increasing grant receipts for Massachusetts. ${ }^{25}$

\section{Data Sources}

The Census Bureau's Annual Survey of Governments and Federal Highway Administration's (FHA) Highway Statistics Series provide two independently-collected sources of data on highway spending and grants and are summarized in Appendix 3. The correlation between these two sources is 0.94 for per-capita highway spending and 0.90 for per-capita highway grants. Table 2 provides summary statistics. Spanning the last three authorizations, corresponding to state fiscal years 1983-1997 and excluding Hawaii, Alaska, and Nebraska, the sample size is $705 .{ }^{26}$ The enactment of the Surface Transportation Assistance Act of 1982, which authorized federal highway grants for fiscal years 1983-1986, marked a shift from interstate construction to interstate maintenance since the interstate system was $95 \%$ complete (Dilger, 1989). Thus, excluding years prior to 1983 makes highway spending and grants from these two sources more comparable over time.

Figures 5 and 6 highlight the two types of variation, cross-sectional and time-series, that have been exploited in previous studies documenting the flypaper effect. Figure 5 depicts 1997 cross-sectional variation among 47 states, demonstrating a strong correlation between federal grants and highway spending and suggesting that federal grants increase public spending more than dollar-for-dollar. However, using this evidence alone, one

${ }^{24}$ Washington Post, June 19, 1991

${ }^{25}$ Washington Post, February 28, 1985

${ }^{26}$ Nebraska is excluded because it has a unicameral, non-partisan legislature and the empirical model below controls for party composition in both chambers of the legislature. Alaska and Hawaii are considered fiscal outliers. 
cannot distinguish between the effect of federal grants on state spending and the correlation between federal grants and preferences for public spending. Figure 6, depicting state highway spending and federal highway grants for the entire United States from 1983 to 1997 , suggests that changes in federal grants over time have influenced aggregate state spending. Alternatively, both federal and state governments may respond to changes in public demand for highways over time. Thus, using these two sources of variation alone, one cannot distinguish between the effect of grants on public spending and a correlation between unobserved preferences and grant levels.

\section{Data considerations}

Although the equivalence prediction of Bradford and Oates applies to lump sum grants, Federal Highway Aid to state governments consists of matching grants. The federal government provides matching funds for state spending on eligible highway projects up to a state-specific cap, at which point the state must begin to provide full funding. ${ }^{27}$ Thus, for states spending more than their cap, the closed-end matching grants are effectively lumpsum grants and are theoretically equivalent to increases in private income. Between 1983 and 1997, virtually all states appear to have spent more on eligible highways than the amount required to exhaust their federal funds and thus face only income effects (see Appendix 4 for details). Furthermore, even if some states are facing price effects, these observations will bias the estimators in favor of finding the flypaper effect since matching grants stimulate more spending than lump-sum grants due to price effects inherent in matching grant programs.

\footnotetext{
27 The Federal and state government shares for interstate projects are currently $90 \%$ and $10 \%$, respectively; other projects on federal-aid highways typically have shares of $80 \%$ and $20 \%$.
} 
A second data consideration relates to the institutional reliance on formulas. The majority of grants in the Federal Highway Aid Program are distributed by a formula relating to state characteristics. ${ }^{28}$ Given this reliance on a formula, it may be difficult for powerful legislators to alter the distribution of grants for the benefit of their home state. If legislators are unable to alter the distribution of formula grants, the empirical model will not be identified since it relies on within-state time-series variation in grant levels and political power. Appendix 5 presents a variance decomposition for grants and reports that a transitory, within-state component accounts for a substantial (18\%) amount of the total variance. ${ }^{29}$ This within-state variation may reflect the numerous means available to politically powerful legislators for altering grant levels, as outlined above in the anecdotal evidence on political bargaining in the Federal Highway Aid Program.

\section{Empirical Model and Results}

\section{Ordinary Least Squares Estimation}

As demonstrated in the theoretical analysis, the correlation between grant levels and preferences for public services biases OLS estimators towards measuring the flypaper effect. As an empirical demonstration of this bias, consider the empirical analogue of equation (5), with observations on states (s) over time (t). For comparability across states, all variables have been converted into per-capita measures. ${ }^{30}$

$$
\operatorname{EXPEND}_{\mathrm{st}}=\alpha+\beta_{1} \mathrm{~A}_{\mathrm{st}}+\beta_{2} \mathrm{M}_{\mathrm{st}}+\mathrm{v}_{\mathrm{st}}
$$

where $\alpha$ is a constant and $\mathrm{v}$ is unobserved heterogeneity.

\footnotetext{
${ }^{28}$ While the formula has changed over time, it has traditionally included interstate lane miles, vehicle miles traveled on the interstate system, the state's share of the cost to complete the interstate system, urbanized population, total population, and total lane miles.

29 This evidence is consistent with Alvarez and Saving (1997) who find that House members on powerful committee are more successful at steering formula grants, relative to project grants, to their home district.

30 To convert Equation (5) into a per-capita expression, simply divide both sides by state population. This percapita specification is consistent with the flypaper literature. (e.g. Moffit (1984)).
} 
A statistical test of $\beta_{1}=\beta_{2}$ examines the equivalence between grants-in-aid and private income.

Column (1) of Table 3 presents the results from this regression using Census data. As found in the literature documenting the flypaper effect, per-capita grants have a far greater effect upon spending than does private income. While the grants coefficient exceeds one, the income coefficient is close to zero. The equivalence test, presented near the bottom of column (1) is easily rejected, with a p-value of essentially zero, providing evidence for the flypaper effect.

\section{Controlling for State Preferences}

The source of the endogeneity of grants is omitted variable bias, a failure to control for preferences that may influence both grant levels and highway spending. As a first attempt at correcting for this omitted variable bias, column (2) includes a set of observable preference measures $(\mathrm{X})$ and state fixed effects $\left(\alpha_{\mathrm{s}}\right)$ as conditioning variables. The addition of these control variables yields the specification:

$$
\operatorname{EXPEND}_{\mathrm{st}}=\alpha_{\mathrm{s}}+\gamma^{\prime} \mathrm{X}_{\mathrm{st}}+\beta_{1} \mathrm{~A}_{\mathrm{st}}+\beta_{2} \mathrm{M}_{\mathrm{st}}+\mathrm{v}_{\mathrm{st}}
$$

The vector $\mathrm{X}$ includes population, drivers per capita, vehicles per capita, and state legislative and governor partisan representation. The population variable measures heterogeneity in preferences due to state size. The next two variables, vehicles and drivers per capita, capture the demand of residents for automobile transportation. The political variables measure differences in preferences across political parties. Finally, state fixed effects control for time-invariant, state-specific heterogeneity. ${ }^{31}$

\footnotetext{
31 Given that highways provide transportation services to constituents, preferences for highway spending may depend upon state spatial variables. These measures include states' square miles, geography, and location within the United States. However, the regressions do not explicitly include these measures since they are time invariant and are thus already incorporated in the state fixed effects.
} 
Column (2) of Table 3 demonstrates a diminished, but still large, flypaper effect. The grants coefficient is now close to one and the income coefficient remains small, although statistically different from zero. Thus, the equivalence test is still easily rejected with a p-value of essentially zero. The third row from the bottom demonstrates that the grants coefficient is statistically similar to one, a finding consistent with the dollar-fordollar flypaper effect prediction of Filimon, Romer, and Rosenthal. The other coefficients in column (2) are insignificant with the exception of the Governor and State House Democrats variables which are both positive, suggesting that Democrats have a stronger preference for highway spending than do Republicans.

These control variables may not completely capture a state's preference for highway spending. Some aspects of preferences, such as attitudes towards public transportation, are unobservable. Similarly, a fixed effect may not correct this endogeneity problem if preferences for public services within a state vary over time. An example of this withinstate variation in preferences is illustrated in Figure 7, which presents time-series variation for California. The increase in highway spending after 1989 reflects a 10 -year project, with a cost estimated up to $\$ 5$ billion, to repair and bolster 2,000 bridges following the October 1989 San Francisco Bay Area earthquake. ${ }^{32}$ In this case, preferences for highway construction varied significantly within the sample period, and a fixed effect may mitigate, but will not eliminate, this endogeneity problem.

\section{Instrumental Variables Estimation}

To address the simultaneous variation in preferences and highway grants, columns (3) and (4) of Table 3 presents the results of a two-stage least-squares (2SLS) estimator. As instruments, the estimator uses three measures of the ability of a state's representatives to

\footnotetext{
32 San Francisco Chronicle, October 16, 1999.
} 
secure federal grants for their constituents: the proportion of representatives on the transportation authorization committee, the proportion of representatives in the majority party, and the average tenure of representatives. In addition, three alternative sets of instruments will serve as a robustness check.

These instruments are all measured in the year of authorization. ${ }^{33}$ I also estimated the empirical model measuring the instruments in the year of appropriation, rather than authorization. However, I found that the authorization measures had more explanatory power in the first-stage regressions. This may reflect the fact that the authorization committee typically generates the formula used to distribute highway funds between states. Further, the anecdotal evidence in Section 4 provides evidence that the authorization committee funded many of the demonstration projects, commonly known as earmarks. The first measure of political power of state delegations, the proportion of a state's representatives serving on the transportation authorization committee, serves as an empirical analog to the committee chair in the bargaining model. ${ }^{34}$ These authorization committees typically propose the distribution of highway funds and then present this proposal to the full legislature with limited amendment opportunities. This agenda-setting power allows the committee members to increase spending for their home state. For example, South Dakota, but not North Dakota, is represented on the House Transportation Committee. Although these two states are similar in size and population, this committee recently earmarked six times more in highway projects for South Dakota than for its

\footnotetext{
33 Thus, while the unit of observation is the state government fiscal year, there is somewhat limited time-series variation in the set of instruments because these funds were authorized only three times between 1983 and 1997.

34 The proportion of representatives may understate the political power of states with large House delegations and overstate the power of states with small delegations. The proportion, rather than the number, of committee members is used since grants are measured in per-capita terms. If committee members from small and large states secure grants similarly, members from small states will secure a larger per-capita grant. Thus, the baseline committee membership is normalized by delegation sizes. As an alternative, results using the number of committee members, not presented here, are very similar to the baseline specifications.
} 
neighbor. In terms of receiving earmarked grants for his home state, "being on the committee was very important", said Representative John Thune (R, SD). ${ }^{35}$ The House Committee on Transportation and Infrastructure and the Senate Environment and Public Works Committee have jurisdiction over transportation authorizations. ${ }^{36}$

The second measure of political power of state delegations, the proportion of a state's representatives in the majority party, captures the importance of party politics. By including members of their own party in the winning coalition, party leaders improve the re-election opportunities of their fellow party members and therefore increase the likelihood of retaining majority control. For example, Massachusetts, which has a delegation dominated by Democrats, was the only state to experience a decrease in federal highway aid during the most recent authorization, the first since the Republicans took control of Congress in $1994 .{ }^{37}$ During all three authorizations for fiscal years 1983-1997, the Democrats controlled the House of Representatives. In the Senate, the Republicans had control during the first authorization, corresponding to fiscal years 1983-1986, and the Democrats controlled the second and third, corresponding to fiscal years 1987-1997.

The third measure of political power of state delegations, the average tenure of the state representatives, captures the importance of tenure in the committee system. The committee chair and minority-ranking member are typically members with the most tenure within the respective party. Even if long-serving representatives do not serve on the transportation committee, there may be logrolling between members of the transportation committee and members of committees with jurisdiction over other spending categories.

\footnotetext{
35 Associated Press, March 26, 1998

36 Shepsle (1978) and Weingast and Marshall (1988) describe the assignment of new Congressional representatives to committees. First, incoming freshmen provide a ranking of their top committee choices, typically listing two or three options. Party leaders then attempt to match these requests with vacant committee seats. In over $80 \%$ of cases, freshmen are assigned to one of their top three choices. Further, Weingast and Marshall (1988) find that legislators request to serve on committees relevant to their constituents' interests.

37 The Boston Globe, March 25, 1998
} 
The 2SLS results are displayed in columns (3) and (4) of Table 3. Focusing on the first-stage results, there is no correlation between per-capita income and grants. States with more drivers receive less grants, perhaps reflecting a collinearity between the drivers and vehicles variables. States with more vehicles per-capita receive larger grants, reflecting the impact of vehicle miles traveled in the aid formula, although this coefficient is statistically insignificant. The state government political party variables have mixed signs. Note that both the first and second-stage of 2SLS also include state fixed effects. ${ }^{38}$

The next six rows of column (3) present the coefficients on the instruments for grants. While four of the six instruments are statistically insignificant, they are jointly significant with an F-statistic of 2.64 and associated p-value of 0.016 . In addition, an overidentification specification test supports the validity of the exclusion restriction assumptions. This test studies the statistic $\mathrm{NR}^{2}$, where $\mathrm{N}$ is the sample size and $\mathrm{R}^{2}$ is the goodness of fit from a regression of the $2^{\text {nd }}$ stage residuals on the instruments and other pre-determined variables (Hausman, 1983).

The coefficients on the three House instruments have a counterintuitive negative sign while the Senate variables have the expected positive sign. There are two possible explanations for this divergence. First, the Democratic party controlled the House, but not the Senate, for the entire sample period, providing little time-series variation in these House instruments, especially the majority party variable. Second, the area represented by Senators, the state, but not the area represented by House representatives, the congressional district, matches the unit of observation in the empirical model. If politically powerful House members increase earmarked projects for their own district at the expense of other districts within their state, this political power may not translate into increased

38 Cornwell, Schmidt, Wyhowski (1992) demonstrate that, as in the case of OLS, linear simultaneous equations model estimators, such as 2SLS, with fixed effects are consistent even without a transformation to sweep out the fixed effects (i.e. a dummy variable specification). 
grants for the state as a whole. For example, the district of Jim Oberstar (D, MN), rankingminority member of the House Transportation Committee, recently received $57 \%$ of the total dollars earmarked for special projects in Minnesota, even though his district represents only $33 \%$ of Minnesota's total square miles and $12 \%$ of the total population. ${ }^{39}$ Alternatively, politically powerful House members may expend their limited resources lobbying for grants with more concentrated, district-specific benefits, such as Housing and Urban Development (HUD) grants to cities and urban counties.

In the second stage, presented in column (4), the grants coefficient of 0.12 is small and statistically similar to the income coefficient of 0.01 . While the grants coefficient has a standard error of 0.42 , which is substantially larger than the fixed effects standard error of 0.06, the point estimate supports the equivalence prediction. Further, this coefficient is statistically different from one, the coefficient associated with the dollar-for-dollar flypaper effect prediction of Filimon, Romer, and Rosenthal (1982). Providing support for the theoretical demonstration of a positive correlation between grants and unobserved preferences, the grants coefficient is much smaller in the endogeneity-corrected estimates than that found using OLS estimators both in this paper and in the previous literature summarized in Table 1. These findings suggest that state governments, in response to federal grants, reduce state taxes, rather than increase spending. Thus, federal grants crowd-out state tax contributions to public services, resulting in no net increase in public spending. Using measures of the political power of state delegations as instruments for federal grants, the dollar-for-dollar flypaper effect disappears, and the point estimates suggest that grants and private income similarly affect public spending.

39 Associated Press, March 26, 1998 


\section{Robustness checks}

While consistent, the 2SLS estimator is biased towards the OLS estimator in finite samples and this bias is especially pronounced if the instruments are only weakly correlated with the endogenous variable. ${ }^{40}$ If the OLS grants coefficient is biased upwards, due to a positive correlation between grant levels and preferences for public spending, then the 2SLS estimator will also be biased towards finding the flypaper effect since the OLS and 2SLS biases operate in the same direction. While limited information maximum likelihood (LIML) and 2SLS are asymptotically equivalent, Staiger and Stock (1997) report that LIML has a smaller finite sample bias and suggest its use as an alternative to 2 SLS. ${ }^{41}$ Appendix 6 provides the likelihood function for the LIML estimator.

Columns (5) and (6) present the LIML results. In the first-stage, the pattern of signs matches that of 2SLS and four out of six are now statistically significant. Similarly to the 2SLS results, the instruments are jointly significant and the over-identification test supports the exclusion restriction assumptions. While the second-stage grants coefficient in column (6) is negative, it is not statistically different from the income coefficient and is again statistically different from one.

As an additional robustness check, Table 4 presents the results using the FHA data. The pattern of coefficients is qualitatively similar to that of Table 3 as the grants coefficient falls in the endogeneity-corrected estimates. In the first stage of 2SLS and LIML, the instruments have the same sign as those in the Census data results. The LIML estimator again reports a negative grants coefficient in the second stage, although it is not statistically different from the income coefficient. Both the 2SLS and LIML estimators reject the dollar-for-dollar flypaper effect.

\footnotetext{
40 See Staiger and Stock (1997) and Bound, Jaeger, and Baker (1995).

${ }^{41}$ LIML assumes a bivariate normal distribution for highway spending and highway grants. By contrast, twostage least squares, a distribution-free estimator, makes assumptions only over the first two moments.
} 
Table 5 presents the Census data results using three alternative sets of instruments. Columns (1) and (2) drop the House variables from the set of instruments given their counterintuitive sign in the baseline specification. In both 2SLS and LIML, the first-stage coefficient on the Senate transportation committee instrument is now statistically significant at the $10 \%$ level, supporting the theoretical prediction that committee members use their agenda-setting power to increase grants for their home state. The 2SLS grants coefficient in column (1) is still close to zero and is statistically different from one at the $10 \%$ level. The LIML estimator in column (2) has a grant coefficient similar to that in the baseline specification and is again statistically different from one. Given the negative signs on the House coefficients in Tables 3 and 4, the remaining instrumental variables results will include only the Senate measures of political power.

The second alternative set of instruments excludes the Senate transportation committee instrument. Marshall and Weingast (1988) provide evidence that legislators choose to serve on committees relevant to their constituent interests. If Senators from states with a strong unobserved demand for highway spending tend to serve on the transportation authorization committee, then this committee variable may be an invalid instrument. In the second stage, the 2SLS grants coefficient in column (3) is larger and no longer statistically different from one, partially reflecting the loss of power from dropping instruments. The LIML grants coefficient in column (4) is again smaller than the 2SLS coefficient. While larger than the baseline specification, these grants coefficients are smaller than the fixed effect grants coefficients in both cases.

Third, given the insignificance of the majority party instrument in Tables 3 and 4, columns (5) and (6) present results using an alternative measure of political power arising from representation in the majority party. This alternative measure is the proportion of Senators serving as majority leader or chair of a standing non-transportation committee. 
This measure may also capture logrolling, an agreement between two chairs to propose projects favorable to each other's states. ${ }^{42}$ For example, in return for a road project, the chair of the Armed Services Committee may propose a military project favorable to the state of the transportation committee chair. In the first-stage of 2SLS, presented in column (5), the committee chair coefficient is large and statistically significant, suggesting that logrolling is a important factor in political bargaining over highway grants. In the secondstage, the grants coefficient is relatively small and significantly different from one at the 95\% level. The LIML results, in column (6) are qualitatively similar, although all three instruments are statistically significant at the $95 \%$ level.

Table 6 presents results using alternative sets of instruments with FHA data. In columns (1) and (2), using Senate instruments alone, the grants coefficients are larger than those in Table 4, which uses the full set of instruments. While the data fail to reject the equivalence test, the coefficients are not statistically different from one, reflecting both a larger grants coefficient and a loss in power from dropping three instruments. Columns (3) and (4) report results that drop the committee instruments and these results are similar to those in columns (1) and (2). Columns (5) and (6) present the results using the alternative measure of power arising from majority party affiliation. Although the grants coefficients remain smaller than the fixed effects coefficients, these results find evidence of a flypaper effect since these coefficients are now statistically different from the income coefficients.

With the exception of the final two coefficients in Table 6, the results from these robustness checks demonstrate that the support of equivalence between income and grants and the rejection of the dollar-for-dollar flypaper effect are robust to two data sources and alternative sets of instruments.

42 Stratmann (1992) examines roll-call votes in Congress and finds evidence of logrolling. 


\section{Conclusion}

In contrast to the previous flypaper effect literature, which typically assumes exogenous variation in federal grants, these results correct for the endogeneity of federal grants and suggest that federal highway grants do not increase state spending on highways. Assuming that these highway grants have only small income effects in other state public spending categories, these highway grants have not significantly increased total state government spending.

This political bargaining explanation for the flypaper effect applies naturally to the federal highway aid program, given its project-based nature, visible benefits for constituents, and historical reputation as a pork-barrel program. Given the uniqueness of this program, political bargaining may not explain the existence of a flypaper effect in other grant programs, such as aid for education and health care. However, grants may be endogenous, or positively correlated with preferences for public services, for many reasons other than political bargaining. For example, federal legislatures seeking an efficient allocation of public goods may provide grants to jurisdictions with the strongest demand for public services. Thus, while this political bargaining explanation of the flypaper effect may be unique to highway grants, a more general critique of endogenous grants may explain the existence of the flypaper effect in other grant programs.

By finding that state governments respond to federal grants by reducing their own tax contributions to public services, this paper adds to the policy crowd-out literature, which examines whether behavioral responses undermine the intent of a public policy. ${ }^{43}$ Since these federal highway grants crowd out tax contributions from state and local

\footnotetext{
${ }^{43}$ Cutler and Gruber (1996) study crowd out of private insurance by publicly provided insurance, which is designed to increase coverage for the uninsured. Gale and Scholz (1994) examine crowd out of non-tax-preferred savings by IRA savings provisions, which are designed to increase national savings. Payne (1998) studies crowd out of private donations to charities by federal grants.
} 
governments, the federal government may need to alter the federal highway aid program in order to increase highway spending by state and local governments. For example, by lowering the match rate from $80 \%$ and raising the limit on matching funds, known as the cap, more states would face the price effects inherent in matching grants and thus should increase highway spending at no additional cost to the federal government.

Another implication of these results is that the political system in the U. S. responds to constituent preferences. The model of Bradford and Oates, which predicts that grants and private income have equivalent effects on public spending, assumes a political system that is responsive to constituent preferences. By contrast, the fiscal illusion model of Filimon, Romer, and Rosenthal, which predicts that grants increase public spending dollarfor-dollar, posits a political system that serves its own, rather than constituent interests. Thus, in finding an equivalence between grants and private income, this paper supports the idea that electoral competition and complete voter information are sufficient to compel elected officials to act in their constituents' interests.

In summary, a legislative bargaining model demonstrated that a positive correlation between grant levels and unobserved preferences biases estimators in the existing literature towards measuring the flypaper effect, even in the context of a model with perfect equivalence between private income and federal grants. Traditional regression methods find evidence for the flypaper effect, as the grants coefficient exceeds the income coefficient. To correct for the correlation between federal grants and preferences for public services, the bargaining model suggests using measures of the political power of state congressional delegations as instruments for grant levels. After using these instruments, the dollar-fordollar flypaper effect disappears and the point estimates suggest that income and grants have similar effects on public spending. 


\section{Appendix 1. Proof of positive correlation between public spending and preferences $\left(\rho_{A, \mu}>0\right)$ in the model with endogenous grants}

As mentioned in the text, assume throughout that representatives from low and high-spending states are equally likely to be assigned to the committee chair:

(11) $\quad \operatorname{Pr}\left(\right.$ chair $\left.\mid \mu_{\mathrm{H}}\right)=\operatorname{Pr}\left(\operatorname{chair} \mid \mu_{\mathrm{L}}\right)=1 / \mathrm{S}$.

Since the covariance and correlation have identical signs, consider the covariance between public spending and preferences:

$$
\sigma_{\mathrm{A}, \mu}=\mathrm{E}(\mu \mathrm{A})-\mathrm{E}(\mu) \mathrm{E}(\mathrm{A})
$$

Apply the law of total probability to the first term of equation (12):

$$
\sigma_{\mathrm{A}, \mu}=\mu_{\mathrm{L}} \operatorname{Pr}\left(\mu_{\mathrm{L}}\right) \mathrm{E}\left(\mathrm{A} \mid \mu_{\mathrm{L}}\right)+\mu_{\mathrm{H}} \operatorname{Pr}\left(\mu_{\mathrm{H}}\right) \mathrm{E}\left(\mathrm{A} \mid \mu_{\mathrm{H}}\right)-\left[\mu_{\mathrm{L}} \operatorname{Pr}\left(\mu_{\mathrm{L}}\right)+\mu_{\mathrm{H}} \operatorname{Pr}\left(\mu_{\mathrm{H}}\right)\right](\mathrm{B} / \mathrm{S})
$$

Next, use the definitions $\operatorname{Pr}\left(\mu_{\mathrm{L}}\right)=\left[\mathrm{S}_{\mathrm{L}} / \mathrm{S}\right]$ and $\operatorname{Pr}\left(\mu_{\mathrm{H}}\right)=\left[1-\left(\mathrm{S}_{\mathrm{L}} / \mathrm{S}\right)\right]$ where $\mathrm{S}_{\mathrm{L}}$ is the number of lowpreference states:

$$
\sigma_{\mathrm{A}, \mu}=\mu_{\mathrm{L}}\left(\mathrm{S}_{\mathrm{L}} / \mathrm{S}\right)\left[\mathrm{E}\left(\mathrm{A} \mid \mu_{\mathrm{L}}\right)-(\mathrm{B} / \mathrm{S})\right]+\mu_{\mathrm{H}}\left[1-\left(\mathrm{S}_{\mathrm{L}} / \mathrm{S}\right)\right]\left[\mathrm{E}\left(\mathrm{A} \mid \mu_{\mathrm{H}}\right)-(\mathrm{B} / \mathrm{S})\right]
$$

Next, note the following accounting identity:

$$
\mathrm{B}=\left(\mathrm{S}_{\mathrm{L}}\right) \mathrm{E}\left(\mathrm{A} \mid \mu_{\mathrm{L}}\right)+\left(\mathrm{S}-\mathrm{S}_{\mathrm{L}}\right) \mathrm{E}\left(\mathrm{A} \mid \mu_{\mathrm{H}}\right)
$$

Solve (15) for $\mathrm{E}\left(\mathrm{A} \mid \mu_{\mathrm{H}}\right)$ :

$$
\mathrm{E}\left(\mathrm{A} \mid \mu_{\mathrm{H}}\right)=\left[\mathrm{B} /\left(\mathrm{S}-\mathrm{S}_{\mathrm{L}}\right)\right]-\left[\mathrm{S}_{\mathrm{L}} /\left(\mathrm{S}-\mathrm{S}_{\mathrm{L}}\right)\right] \mathrm{E}\left(\mathrm{A} \mid \mu_{\mathrm{L}}\right)
$$

Finally, plug (16) into (14) and re-arrange:

$$
\sigma_{\mathrm{A}, \mu}=\left(\mathrm{S}_{\mathrm{L}} / \mathrm{S}\right)\left(\mu_{\mathrm{L}}-\mu_{\mathrm{H}}\right)\left[\mathrm{E}\left(\mathrm{A} \mid \mu_{\mathrm{L}}\right)-(\mathrm{B} / \mathrm{S})\right]
$$

Thus, $\sigma_{\mathrm{A}, \mu}>0$ if and only if $\mathrm{E}\left(\mathrm{A} \mid \mu_{\mathrm{L}}\right)<(\mathrm{B} / \mathrm{S})$.

Since the distinction between low and high-types is arbitrary, equation (17) can be written as follows:

$$
\sigma_{\mathrm{A}, \mu}=\left[1-\left(\mathrm{S}_{\mathrm{L}} / \mathrm{S}\right)\right]\left(\mu_{\mathrm{H}}-\mu_{\mathrm{L}}\right)\left[\mathrm{E}\left(\mathrm{A} \mid \mu_{\mathrm{H}}\right)-(\mathrm{B} / \mathrm{S})\right]
$$

Thus, $\sigma_{\mathrm{A}, \mu}>0$ if and only if $\mathrm{E}\left(\mathrm{A} \mid \mu_{\mathrm{H}}\right)>(\mathrm{B} / \mathrm{S})$.

Finally, to show that the correlation is positive, consider two cases:

$\underline{\text { Case 1: Every high-type in winning coalition }\left[\mathrm{S}_{\mathrm{H}} \leq(\mathrm{S}-1) / 2\right]}$

$$
\mathrm{E}\left(\mathrm{A} \mid \mu_{\mathrm{H}}\right)=\mathrm{E}\left(\mathrm{A} \mid \text { not chair }, \mu_{\mathrm{H}}\right) \operatorname{Pr}(\text { not chair })+\mathrm{E}(\mathrm{A} \mid \text { chair }) \operatorname{Pr}(\text { chair })
$$

Note that every high-type is in the winning coalition and the chair secures more than his tax contribution of B/S:44

\footnotetext{
44 If the chair cannot secure at least his home state's federal tax contribution, he prefers no federal budget. Thus, the chair would propose a federal budget that will not pass.
} 


$$
\mathrm{E}\left(\mathrm{A} \mid \mu_{\mathrm{H}}\right)>\mathrm{B} / \mathrm{S} \operatorname{Pr}(\text { not chair })+\mathrm{B} / \mathrm{S} \operatorname{Pr}(\text { chair })=\mathrm{B} / \mathrm{S}
$$

Thus, according to equation (18), $\sigma_{\mathrm{A}, \mu}>0$.

Case 2: No low-types in winning coalition $\left[\mathrm{S}_{H}>(\mathrm{S}-1) / 2\right]$

$$
\mathrm{E}\left(\mathrm{A} \mid \mu_{\mathrm{L}}\right)=\mathrm{E}\left(\mathrm{A} \mid \text { chair }, \mu_{\mathrm{L}}\right) \operatorname{Pr}(\text { chair })
$$

Note that the chair must pay at least $(\mathrm{B} / \mathrm{S})$ to $(\mathrm{S}-1) / 2$ coalition members:

$$
\mathrm{E}\left(\mathrm{A} \mid \mu_{\mathrm{L}}\right) \leq\{\mathrm{B}-[(\mathrm{S}-1) / 2](\mathrm{B} / \mathrm{S})\}(1 / \mathrm{S})=[(\mathrm{S}+1) / 2 \mathrm{~S}](\mathrm{B} / \mathrm{S})
$$

Finally, since the number of states (S) exceeds 1:

$$
\mathrm{E}\left(\mathrm{A} \mid \mu_{\mathrm{L}}\right)<(\mathrm{B} / \mathrm{S})
$$

Thus, by equation (17), $\sigma_{\mathrm{A}, \mu}>0$.

\section{Appendix 2. Derivation of equivalence test probability limit}

First, consider the probability limit of the two coefficients in a regression of spending on grants and income: 45

$$
\begin{aligned}
& \left.\operatorname{plim}\left(\mathrm{b}_{\mathrm{A}}\right)=\left[\sigma_{\text {EXPEND,A }} \sigma^{2} \mathrm{M}-\sigma_{\text {EXPEND,M }} \sigma_{\mathrm{A}, \mathrm{M}}\right)\right] /\left[\sigma^{2} \mathrm{M} \sigma^{2} \mathrm{~A}-\sigma^{2} \mathrm{~A}, \mathrm{M}\right] \\
& \left.\operatorname{plim}\left(\mathrm{b}_{\mathrm{M}}\right)=\left[\sigma_{\text {EXPEND,M }} \sigma^{2} \mathrm{~A}-\sigma_{\text {EXPEND,A }} \sigma_{\mathrm{A}, \mathrm{M}}\right)\right] /\left[\sigma^{2}{ }_{\mathrm{M}} \sigma^{2} \mathrm{~A}-\sigma^{2} \mathrm{~A}, \mathrm{M}\right]
\end{aligned}
$$

Rules for the covariance of linear functions and the expenditure equation (5) yields the following expressions:

$$
\begin{aligned}
& \sigma_{\text {EXPEND,A }}=\beta \sigma^{2} \mathrm{~A}+\beta \sigma_{\mathrm{A}, \mathrm{M}}+(1-\beta) P \sigma_{\mu}, \mathrm{A} \\
& \sigma_{\text {EXPEND }, \mathrm{M}}=\beta \sigma^{2} \mathrm{M}+\beta \sigma_{\mathrm{A}, \mathrm{M}}+(1-\beta) P \sigma_{\mu, \mathrm{M}}
\end{aligned}
$$

Substitution of equations (26) and (27) into equations (24) and (25) yields:

$$
\begin{aligned}
& \operatorname{plim}\left(\mathrm{b}_{\mathrm{A}}\right)=\beta+(1-\beta) \mathrm{P}\left[\sigma_{\mu}, \mathrm{A}\left(\sigma^{2} \mathrm{M}-\sigma_{\mathrm{A}, \mathrm{M}}\right)\right] /\left[\sigma^{2}{ }_{\mathrm{M}}^{2} \sigma_{\mathrm{A}}-\sigma^{2} \mathrm{~A}, \mathrm{M}\right] \\
& \operatorname{plim}\left(\mathrm{b}_{\mathrm{M}}\right)=\beta+(1-\beta) \mathrm{P}\left[\sigma_{\mu, \mathrm{M}}\left(\sigma_{\mathrm{A}}^{2}-\sigma_{\mathrm{A}, \mathrm{M}}\right)\right] /\left[\sigma^{2}{ }_{\mathrm{M}} \sigma^{2} \mathrm{~A}-\sigma^{2} \mathrm{~A}, \mathrm{M}\right]
\end{aligned}
$$

Consider now the special case of exogenous income $\left(\sigma_{\mu, \mathrm{M}}=0\right)$ and non-redistributive grants $\left(\sigma_{\mathrm{A}, \mathrm{M}}=0\right)$ :

$$
\begin{aligned}
& \operatorname{plim}\left(b_{\mathrm{A}}\right)=\beta+(1-\beta) \mathrm{P}\left(\sigma_{\mu} / \sigma_{\mathrm{A}}\right) \rho_{\mathrm{A}, \mu} \\
& \operatorname{plim}\left(\mathrm{b}_{\mathrm{M}}\right)=\beta
\end{aligned}
$$

\section{Appendix 3. Data sources}

The Census Bureau's Annual Survey of Governments, a survey of state and local governments in the United States, covers financial aspects of highway operations, in addition to all other government functions. By contrast, the Federal Highway Administration's (FHA) Highway

${ }^{45}$ Equations (23) and (24) can be derived by expanding the matrix plim(b) $=\mathrm{E}\left(\mathrm{X}^{\prime} \mathrm{X}\right)^{-1} \mathrm{E}\left(\mathrm{X}^{\prime} \mathrm{Y}\right)$ where $\mathrm{b}$ is the vector of OLS coefficients. 
Statistics Series is a survey of federal, state, and local transportation department officials and covers all aspects of highway operations.

The key distinction between these two sources of data is the treatment of spending on highway law enforcement and safety. The FHA, but not Census, data include this spending in their measure of highway spending and grants. Unfortunately, the FHA data on state grants received from the federal government do not distinguish between highway law enforcement and safety and other types of highway grants. Therefore, one cannot make the two sources of data entirely consistent.

Additionally, the FHA data is missing two observations, Massachusetts (1988) and Vermont (1989), on state highway finances and federal grants to these states. After excluding these two observations, the FHA data sample size is 703 .

\section{Appendix 4. Matching grants analysis}

In order to identify which states spend more than their matching funds and therefore do not face price effects, one would need to know the breakdown between state spending that is eligible and ineligible for federal grants. Unfortunately, neither the Census nor the FHA data distinguish between these types of state highway spending.

There are two pieces of evidence suggesting that these price effects are unimportant. First, Figures $8 \mathrm{a}$ and $8 \mathrm{~b}$ present histograms of federal revenue shares, the proportion of state highway spending financed with federal grants. Figure 8a presents the distribution between 1983 and 1991, a period in which the minimum matching rate was $75 \%$. Figure $8 \mathrm{~b}$ presents a similar distribution for 1992-1997, a period with a minimum rate of $80 \%$. Note that only one observation across these two figures has a federal share exceeding the relevant minimum matching rate.

Assuming eligible and ineligible spending to be perfect substitutes, states would first exhaust federal funds with spending on eligible projects. Indeed, many states have adopted budget rules requiring state transportation departments to first exhaust available federal matching grants before commencing projects that are ineligible for federal aid. ${ }^{46}$ In this case, a federal share that is less than the minimum matching rate, as demonstrated in Figures $8 \mathrm{a}$ and 8b, implies that a state is beyond its matching cap and therefore faces only income effects.

Second, although the study is dated, Miller (1974) analyzed price and income effects in the $\mathrm{ABC}$ program, an older federal-aid system that provided highway grants to states for non-interstate purposes. Using Federal Highway Administration administrative records between 1960-1969, he finds price effects in only eight states, primarily the thinly populated Western states.

In conclusion, while price effects may be important for a few states, these observations should only serve to bias the results towards a measured flypaper effect. According to economic theory, matching grants, which have both price and income effects, stimulate more public spending than do lump-sum grants, which has only income effects. Therefore, the grants coefficient should exceed the income coefficient in an OLS regression of public spending on grants and income, leading to a measured flypaper effect.

\section{Appendix 5. Grants variance decomposition}

A one-way analysis of variance decomposes the variance of grants into a permanent crossstate component and a transitory within-state component. That is, assume that grants are composed of a state-specific permanent component $\left(\mu_{\mathrm{s}}\right)$ and a state and time-specific transitory component $\left(v_{\mathrm{st}}\right)$ :

$$
\mathrm{A}_{\mathrm{st}}=\mu_{\mathrm{s}}+v_{\mathrm{st}}
$$

Then, assuming that these components are independent of each other, the variance in grants can be decomposed as follows:

${ }^{46}$ Conversation with Tom Benedict, U.S. Department of Transportation. 


$$
\operatorname{var}\left(\mathrm{A}_{\mathrm{st}}\right)=\operatorname{var}\left(\mu_{\mathrm{s}}\right)+\operatorname{var}\left(v_{\mathrm{st}}\right)
$$

These components of equation (33) are then estimated using a standard analysis of variance (ANOVA) procedure. For each state, this analysis uses three observations, the average grant level for each authorization period. A similar analysis was performed with all 705 observations, the grant level for each state in each year, and the results were similar. In each case, the transitory and permanent variance components accounted for $18 \%$ and $82 \%$, respectively, of the total variance in grant levels.

\section{Appendix 6. LIML likelihood function}

Consider the structural equation (10) and a reduced form equation for grants:

$$
\begin{aligned}
& \text { EXPEND }=\gamma^{\prime} \mathrm{X}+\beta_{1} \mathrm{~A}+\mathrm{V} \\
& \mathrm{A}=\pi^{\prime} \mathrm{X}+\theta^{\prime} \mathrm{Z}+\mathrm{U}
\end{aligned}
$$

where $\mathrm{Z}$ is the set of instruments. Note that the income variable and the fixed effects from equation (10) have been incorporated into the vector $\mathrm{X}$ and that the state and time subscripts have been dropped.

Substituting equation (35) into (34) yields a reduced form equation for expenditures:

$$
\operatorname{EXPEND}=\left(\gamma^{\prime}+\beta_{1} \pi^{\prime}\right) \mathrm{X}+\beta_{1} \theta^{\prime} \mathrm{Z}+\mathrm{W}
$$

where $\mathrm{W}=\beta_{1} \mathrm{U}+\mathrm{V}$

Assuming $\mathrm{U}$ and $\mathrm{V}$ to be distributed jointly normal, $\mathrm{U}$ and $\mathrm{W}$ will also be distributed jointly normal with the following log-likelihood (for a single observation):

$$
\ln [\mathrm{f}(\mathrm{U}, \mathrm{W})]=-\ln \left[\mathrm{s}_{\mathrm{U}} \mathrm{s}_{\mathrm{w}} \sqrt{1-?^{2}}\right]-\frac{1}{2\left(1-?^{2}\right)} \exp \left[\frac{-1}{2\left(1-?^{2}\right)}\right] \exp \left\{\left[\frac{\mathrm{W}}{\mathrm{s}_{\mathrm{W}}}\right]^{2}+\left[\frac{\mathrm{U}}{\mathrm{s}_{\mathrm{U}}}\right]^{2}-2 ? \frac{\mathrm{W}}{\mathrm{s}_{\mathrm{W}}} \times \frac{\mathrm{U}}{\mathrm{s}_{\mathrm{U}}}\right\}
$$

where $\sigma_{\mathrm{U}}$ and $\sigma_{\mathrm{W}}$ are the respective standard deviations and $\rho$ is the correlation between $\mathrm{U}$ and $\mathrm{W}$. Substituting for U and W from equations (35) and (36) and summing across all observations yields the sample log likelihood of observed variables and parameters. 


\section{References}

Alvarez, R. and J. Saving, Congressional Committees and the Political Economy of Federal Outlays, Public Choice, 92, 1997.

Bailey, S. and S. Connolly, The Flypaper Effect: Identifying Areas for Further Research, Public Choice, 95, 1998.

Baron, D. and J. Ferejohn, Bargaining in Legislatures, American Political Science Review, 83(4), 1989.

Baron, D. and J. Ferejohn, Bargaining and Agenda Formation in Legislatures, American Economic Review, 77(2), 1987.

Becker, E., The Illusion of Fiscal Illusion: Unsticking the Flypaper Effect, Public Choice, 86(1), 1996.

Besley, T. and A. Case, Unnatural Experiments? Estimating the Incidence of Endogenous Policies, NBER working paper \#4956, 1994.

Besley, T. and S. Coate, An Economic Model of Representative Democracy, Quarterly Journal of Economics, 112(4), 1997.

Besley, T. and S. Coate, Centralized versus Decentralized Provision of Local Public Goods: A Political Economy Analysis, NBER working paper \#7084, 1999.

Bound, J., D. Jaeger, and R. Baker, Problems With Instrumental Variables Estimation When the Correlation Between the Instruments and the Endogenous Explanatory Variable is Weak, Journal of the American Statistical Association, 90(430), 1995.

Bowman, J., Tax Exportability, Intergovernmental Aid, and School Finance Reform, National Tax Journal, 27, 1974.

Bradford, D. and W. Oates, The Analysis of Revenue Sharing in a New Approach to Collective Fiscal Decisions, Quarterly Journal of Economics, 85(3), 1971a.

Bradford, D. and W. Oates, Towards a Predictive Theory of Intergovernmental Grants, American Economic Review, 61(2), 1971b.

Case, A., J. Hines, and H. Rosen, Budget Spillovers and Fiscal Policy Interdependence: Evidence from the States" Journal of Public Economics, 52, 1993.

Chari, V., L. Jones, and R. Marimon, The Economics of Split-Ticket Voting in Representative Democracies, American Economic Review, 87, 1997.

Chernick, H., An Economic Model of the Distribution of Project Grants, in Fiscal Federalism and Grants-in-Aid, The Urban Institute, 1979.

Chernick, H., Price Discrimination and Federal Project Grants, Public Finance Quarterly, 9, 1981.

Cornwell, C., P. Schmidt, and D. Wyhowski, Simultaneous Equations and Panel Data, Journal of Econometrics, 51, 1992. 
Courant, P., E. Gramlich, and D. Rubinfield, The Stimulative Effects of Intergovernmental Grants, or Why Money Sticks Where it Hits, in Fiscal Federalism and Grants in Aid, The Urban Institute, 1979.

Cutler, D., and J. Gruber, Does Public Insurance Crowd Out Private Insurance, Quarterly Journal of Economics, 111, 1996.

Dilger, R., National Intergovernmental Programs, Prentice Hall, 1989.

Evans, D., Policy and Pork: The Use of Pork Barrel Projects to Build Policy Coalitions in the House of Representatives, American Journal of Political Science, 38, 1994.

Federal Highway Administration, Office of Highway Information Management, $\underline{\text { Highway Statistics, }}$ various years.

Feldstein, M., Wealth Neutrality and Local Choice in Public Education,American Economic Review, 65, 1975.

Filimon, R., Romer, T. and H. Rosenthal, Asymmetric Information and Agenda Control, Journal of Public Economics, 17, 1982.

Gale, W. and K. Scholz, IRAs and Household Savings, American Economic Review, 84, 1994.

Gamkhar, S. and W. Oates, Asymmetries in the Response to Increases and Decreases in Intergovernmental Grants: Some Empirical Findings, National Tax Journal, 49, 1996.

Gramlich E., and H. Galper, State and Local Fiscal Behavior and Federal Grant Policy, Brookings Papers on Economic Activity, 1, 1973.

Gramlich, E., Intergovernmental Grants: A Review of the Empirical Literature, in The Political Economy of Fiscal Federalism. Wallace Oates, ed., Heath Lexington, 1977.

Grossman, P., The Impact of Federal and State Grants on Local Government Spending: A Test of the Fiscal Illusion Hypothesis, Public Finance Quarterly, 18, 1990.

Hamilton, B., The Flypaper Effect and Other Anomalies, Journal of Public Economics, 22, 1983.

Hausman, J., Specification and Estimation of Simultaneous Equations Models, in Handbook of Econometrics, Volume 1, North-Holland Publishing Company, 1983.

Hines, J. and R. Thaler, The Flypaper Effect, Journal of Economic Perspectives, 9, 1995.

Inman, R., Towards an Econometric Model of Local Budgeting, in Proceedings of the 64th Annual Conference on Taxation, National Tax Association, 1971.

Miller, E., The Economics of Matching Grants: The ABC Highway Program, National Tax Journal, 27, 1974.

Moffit, R., The Effects of Grants-in-Aid on State and Local Expenditures: the Case of AFDC, Journal of Public Economics, 23, 1984.

Oates, W., Fiscal Federalism, Harcourt Brace, 1972. 
Oates, W., Federalism and Public Finance, in Modern Public Finance, J. Quigley and E. Smolensky, eds., Harvard University Press, 1994.

Oates, W., An Essay on Fiscal Federalism, Journal of Economic Literature, 37, 1999.

Olmstead G., A. Denzan, and J. Roberts, We Voted for This? Institutions and Educational Spending, Journal of Public Economics, 52, 1993.

Payne, A., Does the Government Crowd-Out Private Donations? New Evidence from a Sample of Non-Profit Firms, Journal of Public Economics, 69, 1998.

Poterba J., S. Venti, and D. Wise, Do 401(k) Contributions Crowd Out Other Personal Savings, Journal of Public Economics, 58, 1995.

Romer, T. and H. Rosenthal, Political Resource Allocation, Controlled Agendas, and the Status Quo, Public Choice, 33, 1978.

Romer, T. and H. Rosenthal, The Elusive Median Voter, Journal of Public Economics, 12, 1979a.

Romer, T. and H. Rosenthal, Bureaucrats Versus Voters: on the Political Economy of Resource Allocation by Direct Democracy, Quarterly Journal of Economics, 93, 1979b.

Shepsle, K., The Giant Jigsaw Puzzle: Democratic Committee Assignments in the Modern House (University of Chicago Press), 1978.

Staiger, D. and J. Stock, Instrumental Variables Regression with Weak Instruments, Econometrica, 65(3), 1997.

Stratmann, T., The Effects of Logrolling on Congressional Voting, American Economic Review, 82, 1992.

Weicher, J., Aid, Expenditures, and Local Government Structure, National Tax Journal, 25, 1972.

Weingast, B., K. Shepsle, and C. Johnsen, The Political Economy of Benefits and Costs: A

Neoclassical Approach to Distributive Politics, Journal of Political Economy, 89(4), 1981.

Weingast, B., and W. Marshall, The Industrial Organization of Congress; or, Why Legislatures, Like Firms, Are Not Organized as Markets, Journal of Political Economy, 96, 1988.

Winer, S., Some Evidence on the Effect of the Separation of Spending and Taxing Decisions, Journal of Political Economy, 91(1), 1983.

Wittman, D., Why Democracies Produce Efficient Results, Journal of Political Economy, 97(6), 1989.

Wyckoff, P., The Elusive Flypaper Effect, Journal of Urban Economics, 30, 1991. 
Table 1

Measures of the flypaper effect:

Representative estimates of marginal propensities to consume public services adapted from Hines and Thaler (1995)

\begin{tabular}{|c|c|c|c|c|}
\hline Author & Sample & $\begin{array}{l}\text { MPC } \\
\text { from } \\
\text { income }\end{array}$ & $\begin{array}{l}\text { MPC from } \\
\text { grants }\end{array}$ & Other covariates \\
\hline Inman (1971) & $\begin{array}{l}\text { State grants to } 41 \text { cities, } \\
1967\end{array}$ & 0.04 & 1.34 & none \\
\hline $\begin{array}{l}\text { Weicher } \\
(1972)\end{array}$ & $\begin{array}{l}\text { State grants to } 106 \\
\text { municipal governments, } \\
1962\end{array}$ & 0.02 & 0.91 & $\begin{array}{l}\text { total pop., empl. rate, pop. growth, pop. } \\
\text { density, housing characteristics, retail } \\
\text { sales, mfg. establishments, central city pop. } \\
\text { and mfg., percent of pop.: school-aged, < age } \\
\text { 21, non-white, foreign }\end{array}$ \\
\hline $\begin{array}{l}\text { Weicher } \\
(1972)\end{array}$ & $\begin{array}{l}\text { State grants to } 106 \\
\text { school districts, } 1962\end{array}$ & 0.02 & 0.59 & see above \\
\hline $\begin{array}{l}\text { Gramlich, } \\
\text { Galper (1973) }\end{array}$ & $\begin{array}{l}\text { Federal grants to state } \\
\text { and local governments, } \\
\text { quarterly 1954-1972 } \\
\text { (time-series) }\end{array}$ & 0.10 & 0.43 & $\begin{array}{l}\text { relative price of capital, proportion of } \\
\text { school-aged, female-headed families, } \\
\text { robbery rate }\end{array}$ \\
\hline $\begin{array}{l}\text { Gramlich, } \\
\text { Galper (1973) }\end{array}$ & $\begin{array}{l}\text { Federal and state aid to } \\
10 \text { large urban } \\
\text { governments, 1962-1970 } \\
\text { (panel) }\end{array}$ & 0.05 & 0.25 & $\begin{array}{l}\text { grant price effects, robbery rate, suburban } \\
\text { taxes }\end{array}$ \\
\hline $\begin{array}{l}\text { Bowman } \\
(1974)\end{array}$ & $\begin{array}{l}\text { Federal education grants } \\
\text { to } 55 \text { WestVirginia school } \\
\text { districts, } 1970\end{array}$ & $\mathrm{n} / \mathrm{a}^{2}$ & 1.06 & $\begin{array}{l}\text { non-local assessed value, population } \\
\text { growth, local assessed value, percent of } \\
\text { families with income }>\$ 15,000 \text {, percent of } \\
\text { families with children }<\text { age } 18\end{array}$ \\
\hline $\begin{array}{l}\text { Bowman } \\
(1974)\end{array}$ & $\begin{array}{l}\text { State grants to } 55 \text { West } \\
\text { Virginia school districts, } \\
1970\end{array}$ & $\mathrm{n} / \mathrm{a}^{2}$ & 0.50 & $\begin{array}{l}\text { pop. growth, local and non-local assessed } \\
\text { value, } \% \text { of families with income }>\$ 15 \mathrm{~K}, \% \\
\text { of families with children < age } 18\end{array}$ \\
\hline $\begin{array}{l}\text { Feldstein } \\
(1975)\end{array}$ & $\begin{array}{l}\text { State education grants to } \\
105 \text { Massachusetts } \\
\text { towns, } 1970\end{array}$ & $\mathrm{n} / \mathrm{a}^{3}$ & 0.60 & $\begin{array}{l}\text { wealth, match rate, tax base, private school } \\
\text { pupils per-capita public school pupils per- } \\
\text { capita, growth in pupils }\end{array}$ \\
\hline Winer (1983) & $\begin{array}{l}\text { Federal grants to } \\
\text { Canadian provinces, } \\
1952-1969 \text { (panel) } \\
\end{array}$ & $\mathrm{n} / \mathrm{a}^{4}$ & 1.20 & population, province fixed effects \\
\hline $\begin{array}{l}\text { Grossman } \\
(1990)\end{array}$ & $\begin{array}{l}\text { State and federal grants } \\
\text { to } 136 \text { Virginia local } \\
\text { governments, } 1981\end{array}$ & 0.01 & 1.70 & $\begin{array}{l}\text { median voter tax price, urban population, } \\
\text { black population }\end{array}$ \\
\hline $\begin{array}{l}\text { Olmsted, } \\
\text { Denzau, } \\
\text { Roberts } \\
(1993)\end{array}$ & $\begin{array}{l}\text { State and federal grants } \\
\text { to } 344 \text { Missouri school } \\
\text { districts, } 1980\end{array}$ & 0.05 & $0.58-1.15$ & $\begin{array}{l}\text { tax price, number of students in private } \\
\text { school, number pupils, \% pop.: urban, poor, } \\
\text { black, homeowners, }\end{array}$ \\
\hline $\begin{array}{l}\text { Case, Hines, } \\
\text { Rosen (1993) }\end{array}$ & $\begin{array}{l}\text { Federal grants to states } \\
1970-1985 \text { (panel) }\end{array}$ & $\begin{array}{l}0.11- \\
0.17\end{array}$ & $0.65-1.04$ & $\begin{array}{l}\text { population density, } \% \text { pop. }>65, \% \text { pop. } 5- \\
17, \% \text { pop. black }\end{array}$ \\
\hline Becker (1994) & $\begin{array}{l}\text { Federal grants to state } \\
\text { and local governments, } \\
1977-1986 \text { (panel) }\end{array}$ & 0.06 & 0.61 & tax price, lagged expenditures \\
\hline $\begin{array}{l}\text { Gamkhar, } \\
\text { Oates (1996) }\end{array}$ & $\begin{array}{l}\text { Federal grants to state } \\
\text { governments, 1953-1991 } \\
\text { (time-series) }\end{array}$ & 0.11 & 0.62 & $\begin{array}{l}\text { unemployment, share of population school- } \\
\text { aged, percent of population urban }\end{array}$ \\
\hline
\end{tabular}

\section{footnotes:}

1. Logarithmic estimates have been converted into marginal effects, where appropriate.

2. Bowman uses the percent of families with income $>\$ 15,000$, rather than the level of income.

3. Feldstein uses a logarithmic specification but does not provide the sample average for per-capita income, information necessary to convert the income coefficient into a MPC.

4. Winer uses per-capita income but total grants and public spending. In addition, he does not provide a sample average for spending, information necessary to convert the income coefficient into a MPC. 
Table 2

Summary statistics

47 states, fiscal years 1983-1997

705 observations (703 for FHA data)

all monetary values in 1997 dollars

\begin{tabular}{|c|c|c|c|}
\hline Variable & Definition & $\begin{array}{l}\text { Sample average } \\
\text { (std. deviation) }\end{array}$ & Source \\
\hline $\begin{array}{l}\text { Census per- } \\
\text { capita spending }\end{array}$ & $\begin{array}{l}\text { Per-capita state government spending on } \\
\text { construction, maintenance, and operation of } \\
\text { highways, streets and related structures, including } \\
\text { grants to local governments, fiscal year (Census } \\
\text { definition) }\end{array}$ & $\begin{array}{r}264.88 \\
(98.75)\end{array}$ & $\begin{array}{l}\text { Census Bureau Survey } \\
\text { of Governments }\end{array}$ \\
\hline $\begin{array}{l}\text { Census per- } \\
\text { capita grants }\end{array}$ & $\begin{array}{l}\text { Per-capita federal aid to state governments for } \\
\text { highway spending, fiscal year }\end{array}$ & $\begin{array}{r}92.43 \\
(44.73)\end{array}$ & $\begin{array}{l}\text { Census Bureau Survey } \\
\text { of Governments }\end{array}$ \\
\hline $\begin{array}{l}\text { FHA per-capita } \\
\text { spending }\end{array}$ & $\begin{array}{l}\text { Per-capita state government spending on } \\
\text { construction, maintenance, administration, and law } \\
\text { enforcement / safety including grants to local } \\
\text { governments, fiscal year (FHA definition) }\end{array}$ & $\begin{array}{r}292.95 \\
(100.84)\end{array}$ & $\begin{array}{l}\text { FHA Highway } \\
\text { Statistics Series }\end{array}$ \\
\hline $\begin{array}{l}\text { FHA per-capita } \\
\text { grants }\end{array}$ & $\begin{array}{l}\text { Per-capita federal aid to state governments for } \\
\text { highway spending, fiscal year }\end{array}$ & $\begin{array}{r}98.41 \\
(60.06) \\
\end{array}$ & $\begin{array}{l}\text { FHA Highway } \\
\text { Statistics Series }\end{array}$ \\
\hline $\begin{array}{l}\text { Per-capita } \\
\text { personal income }\end{array}$ & $\begin{array}{l}\text { State per-capita personal income before taxes, } \\
\text { calendar year }\end{array}$ & $\begin{array}{l}21,761.64 \\
(3,693.73)\end{array}$ & $\begin{array}{l}\text { Bureau of Economic } \\
\text { Analysis Regional } \\
\text { Accounts Data }\end{array}$ \\
\hline Population & in millions & $\begin{array}{r}5.24 \\
(5.47)\end{array}$ & $\begin{array}{l}\text { Bureau of Economic } \\
\text { Analysis Regional } \\
\text { Accounts Data }\end{array}$ \\
\hline $\begin{array}{l}\text { Drivers per } \\
\text { capita }\end{array}$ & Number of registered drivers per capita & $\begin{array}{r}0.68 \\
(0.05) \\
\end{array}$ & $\begin{array}{l}\text { FHA Highway } \\
\text { Statistics Series }\end{array}$ \\
\hline $\begin{array}{l}\text { Vehicles per } \\
\text { capita }\end{array}$ & $\begin{array}{l}\text { Number of registered automobiles, buses, and trucks } \\
\text { per capita }\end{array}$ & $\begin{array}{r}0.79 \\
(0.11) \\
\end{array}$ & $\begin{array}{l}\text { FHA Highway } \\
\text { Statistics Series }\end{array}$ \\
\hline $\begin{array}{l}\text { Governor } \\
\text { Democrat }\end{array}$ & Indicator for Democratic Party governor & $\begin{array}{r}0.57 \\
(0.50)\end{array}$ & The Book of the States \\
\hline $\begin{array}{l}\text { State House } \\
\text { Democrats }\end{array}$ & $\begin{array}{l}\text { Percentage of State House represented by } \\
\text { Democratic Party }\end{array}$ & $\begin{array}{r}0.58 \\
(0.25)\end{array}$ & The Book of the States \\
\hline $\begin{array}{l}\text { State Senate } \\
\text { Democrats }\end{array}$ & $\begin{array}{l}\text { Percentage of State Senate represented by } \\
\text { Democratic Party }\end{array}$ & $\begin{array}{r}0.55 \\
(0.35) \\
\end{array}$ & The Book of the States \\
\hline $\begin{array}{l}\text { U.S. House } \\
\text { transportation }\end{array}$ & $\begin{array}{l}\text { Percentage of state representatives to U.S. House on } \\
\text { transportation authorization committee }\end{array}$ & $\begin{array}{r}0.10 \\
(0.13)\end{array}$ & $\begin{array}{l}\text { Almanac of American } \\
\text { Politics }\end{array}$ \\
\hline $\begin{array}{l}\text { U.S. House } \\
\text { majority party }\end{array}$ & $\begin{array}{l}\text { Percentage of state representatives to U.S. House in } \\
\text { majority party (in year grants authorized) }\end{array}$ & $\begin{array}{r}0.58 \\
(0.25)\end{array}$ & $\begin{array}{l}\text { Roster of U.S. } \\
\text { Congressional Office- } \\
\text { holders (ICPSR \#7803) }\end{array}$ \\
\hline $\begin{array}{l}\text { U.S. House } \\
\text { tenure }\end{array}$ & $\begin{array}{l}\text { Average tenure of state representatives in U.S. } \\
\text { House (in year grants authorized) }\end{array}$ & $\begin{array}{r}7.87 \\
(3.72)\end{array}$ & $\begin{array}{l}\text { Roster of U.S. } \\
\text { Congressional Office- } \\
\text { holders (ICPSR \#7803) }\end{array}$ \\
\hline $\begin{array}{l}\text { U.S. Senate } \\
\text { transportation }\end{array}$ & $\begin{array}{l}\text { Percentage of state representatives to U.S. Senate on } \\
\text { transportation authorization committee }\end{array}$ & $\begin{array}{r}0.17 \\
(0.24) \\
\end{array}$ & $\begin{array}{l}\text { Almanac of American } \\
\text { Politics }\end{array}$ \\
\hline $\begin{array}{l}\text { U.S. Senate } \\
\text { majority party }\end{array}$ & $\begin{array}{l}\text { Percentage of state representatives to U.S. Senate in } \\
\text { majority party (in year grants authorized) }\end{array}$ & $\begin{array}{r}0.55 \\
(0.36)\end{array}$ & $\begin{array}{l}\text { Roster of U.S. } \\
\text { Congressional Office- } \\
\text { holders (ICPSR \#7803) } \\
\end{array}$ \\
\hline $\begin{array}{l}\text { U.S. Senate } \\
\text { tenure }\end{array}$ & $\begin{array}{l}\text { Average tenure of state representatives in U.S. } \\
\text { Senate (in year grants authorized) }\end{array}$ & $\begin{array}{r}9.48 \\
(5.60)\end{array}$ & $\begin{array}{l}\text { Roster of U.S. } \\
\text { Congressional Office- } \\
\text { holders (ICPSR \#7803) }\end{array}$ \\
\hline $\begin{array}{l}\text { U.S. Senate } \\
\text { committee chair }\end{array}$ & $\begin{array}{l}\text { Percentage of state representatives to U.S. Senate } \\
\text { serving as majority leader or chair of standing non- } \\
\text { transportation committee (in year grants authorized) }\end{array}$ & $\begin{array}{r}0.15 \\
(0.23)\end{array}$ & $\begin{array}{l}\text { Almanac of American } \\
\text { Politics }\end{array}$ \\
\hline
\end{tabular}


Table 3

Estimates of the flypaper effect

Census Bureau Survey of Governments data

(** denotes $5 \%$ significance, * denotes $10 \%$ significance)

\begin{tabular}{|c|c|c|c|c|c|c|}
\hline & (1) & (2) & (3) & $(4)$ & (5) & (6) \\
\hline & OLS & Fixed Effects & 2SLS $1^{\text {st }}$ Stage & 2SLS 2 ${ }^{\text {nd }}$ Stage & LIML $1^{\text {st }}$ Stage & LIML $2^{\text {nd }}$ Stage \\
\hline $\begin{array}{l}\text { Dependent } \\
\text { variable }\end{array}$ & $\begin{array}{l}\text { Per-capita } \\
\text { spending }\end{array}$ & \begin{tabular}{|l} 
Per-capita \\
spending
\end{tabular} & $\begin{array}{l}\text { Per-capita } \\
\text { grants }\end{array}$ & $\begin{array}{l}\text { Per-capita } \\
\text { spending }\end{array}$ & \begin{tabular}{|l|}
$\begin{array}{l}\text { Per-capita } \\
\text { grants }\end{array}$ \\
\end{tabular} & $\begin{array}{l}\text { Per-capita } \\
\text { spending }\end{array}$ \\
\hline Per-capita grants & $\begin{array}{l}1.6895 \\
(0.3380)^{* *}\end{array}$ & $\begin{array}{l}0.9664 \\
(0.0560)^{* *}\end{array}$ & & $\begin{array}{l}0.1203 \\
(0.4205) \\
\end{array}$ & & $\begin{array}{l}-0.1168 \\
(0.4921) \\
\end{array}$ \\
\hline Per-capita income & $\begin{array}{l}-0.0008 \\
(0.0016)\end{array}$ & $\begin{array}{l}0.0094 \\
(0.0011)^{* *}\end{array}$ & $\begin{array}{c}0.0004 \\
(0.0008)\end{array}$ & $\begin{array}{l}0.0100 \\
(0.0013) * *\end{array}$ & $\begin{array}{l}0.0005 \\
(0.0007)\end{array}$ & $\begin{array}{l}0.0101 \\
(0.0013)^{* *}\end{array}$ \\
\hline Population & & $\begin{array}{l}1.1564 \\
(2.9468) \\
\end{array}$ & $\begin{array}{l}-1.6342 \\
(2.0633)\end{array}$ & $\begin{array}{l}-0.6395 \\
(3.5377) \\
\end{array}$ & $\begin{array}{l}-1.7573 \\
(1.9720)\end{array}$ & $\begin{array}{l}-1.1427 \\
(3.7003) \\
\end{array}$ \\
\hline Drivers per capita & & $\begin{array}{l}-49.6321 \\
(47.5530)\end{array}$ & $\begin{array}{l}-93.6733 \\
(33.7381)^{* *}\end{array}$ & $\begin{array}{l}-117.1277 \\
(64.4603)^{*}\end{array}$ & $\begin{array}{l}-87.7025 \\
(32.1501)^{* *}\end{array}$ & $\begin{array}{l}-136.0395 \\
(69.2737)^{*}\end{array}$ \\
\hline Vehicles per capita & & $\begin{array}{l}-46.0429 \\
(28.5717) \\
\end{array}$ & $\begin{array}{c}31.9718 \\
(20.2794)\end{array}$ & $\begin{array}{l}26.5320 \\
(34.5729) \\
\end{array}$ & $\begin{array}{l}33.8116 \\
(19.3037)^{*}\end{array}$ & $\begin{array}{l}-21.0652 \\
(36.2342) \\
\end{array}$ \\
\hline $\begin{array}{l}\text { Governor } \\
\text { Democrat }\end{array}$ & & $\begin{array}{l}7.9057 \\
(2.9364)^{* *}\end{array}$ & $\begin{array}{l}-1.6286 \\
(2.0635)\end{array}$ & $\begin{array}{l}6.1663 \\
(3.5193)^{*}\end{array}$ & $\begin{array}{l}-1.7703 \\
(1.9692)\end{array}$ & $\begin{array}{c}5.6789 \\
(3.6793)\end{array}$ \\
\hline $\begin{array}{l}\text { State House } \\
\text { Democrats }\end{array}$ & & $\begin{array}{l}44.6914 \\
(23.3299)^{*}\end{array}$ & $\begin{array}{l}-25.0305 \\
(16.7617)\end{array}$ & $\begin{array}{c}24.3438 \\
(28.9063)\end{array}$ & $\begin{array}{l}-25.0374 \\
(15.8478)\end{array}$ & $\begin{array}{l}18.6425 \\
(30.4721)\end{array}$ \\
\hline $\begin{array}{l}\text { State Senate } \\
\text { Democrats }\end{array}$ & & $\begin{array}{l}8.7986 \\
(18.9422) \\
\end{array}$ & \begin{tabular}{|l}
25.2291 \\
$(13.9681)^{*}$
\end{tabular} & $\begin{array}{c}29.0516 \\
(24.1645) \\
\end{array}$ & $\begin{array}{l}28.0665 \\
(13.0827)^{* *} \\
\end{array}$ & \begin{tabular}{|c|}
34.7264 \\
$(25.6452)$
\end{tabular} \\
\hline $\begin{array}{l}\text { U.S. House trans. } \\
\text { cmte. }\end{array}$ & & & $\begin{array}{l}3.9931 \\
(9.3301)\end{array}$ & & $\begin{array}{l}-4.6705 \\
(7.0926)\end{array}$ & \\
\hline $\begin{array}{l}\text { U.S. House maj. } \\
\text { Party }\end{array}$ & & & $\begin{array}{l}-7.9498 \\
(6.4769) \\
\end{array}$ & & $\begin{array}{l}-11.6845 \\
(4.9914) * *\end{array}$ & \\
\hline U.S. House tenure & & & $\begin{array}{l}-0.9650 \\
(0.4264)^{* *}\end{array}$ & & $\begin{array}{l}-0.6963 \\
(0.3754) *\end{array}$ & \\
\hline $\begin{array}{l}\text { U.S. Senate trans. } \\
\text { cmte. }\end{array}$ & & & $\begin{array}{l}9.1667 \\
(6.2829)\end{array}$ & & $\begin{array}{l}11.7331 \\
(4.9182)^{* *}\end{array}$ & \\
\hline $\begin{array}{l}\text { U.S. Senate maj. } \\
\text { party }\end{array}$ & & & $\begin{array}{c}1.1435 \\
(2.9089)\end{array}$ & & $\begin{array}{l}1.6147 \\
(2.2081)\end{array}$ & \\
\hline U.S. Senate tenure & & & $\begin{array}{l}0.9237 \\
(0.2953)^{* *}\end{array}$ & & $\begin{array}{l}0.7644 \\
(0.2821)^{* *}\end{array}$ & \\
\hline Observations & 705 & 705 & 705 & 705 & 705 & 705 \\
\hline $\mathrm{R}$-squared & 0.5941 & 0.9080 & 0.7849 & & & \\
\hline state fixed effects & no & yes & yes & yes & yes & yes \\
\hline $\begin{array}{l}\text { equivalence test } \mathrm{p} \text { - } \\
\text { value }\left[\mathrm{H}_{0}: \beta_{1}=\beta_{2}\right]\end{array}$ & 0.000 & 0.000 & & 0.793 & & 0.797 \\
\hline $\begin{array}{l}\text { fiscal illusion test } \\
\text { p-value }\left[H_{0}: \beta_{1}=1\right]\end{array}$ & 0.047 & 0.548 & & 0.037 & & 0.023 \\
\hline $\begin{array}{l}\text { over idendification } \\
\text { test p-value }\end{array}$ & & & & 0.577 & & 0.631 \\
\hline $\begin{array}{l}\text { instrument F-test } \\
\text { (p-value) }\end{array}$ & & & $\begin{array}{l}2.64 \\
(0.016) \\
\end{array}$ & & \begin{tabular}{|l}
2.65 \\
$(0.015)$ \\
\end{tabular} & \\
\hline
\end{tabular}


Table 4

Estimates of the flypaper effect

Federal Highway Administration Highway Statistics data

(** denotes $5 \%$ significance, * denotes $10 \%$ significance)

\begin{tabular}{|c|c|c|c|c|c|c|}
\hline & (1) & (2) & (3) & (4) & (5) & (6) \\
\hline & OLS & Fixed Effects & 2SLS $1^{\text {st }}$ Stage & 2SLS 2nd Stage & LIML $1^{\text {st }}$ Stage & LIML $2^{\text {nd }}$ Stage \\
\hline $\begin{array}{l}\text { Dependent } \\
\text { variable }\end{array}$ & $\begin{array}{l}\text { Per-capita } \\
\text { spending }\end{array}$ & \begin{tabular}{|l|} 
Per-capita \\
spending
\end{tabular} & \begin{tabular}{|l|} 
Per-capita \\
grants
\end{tabular} & $\begin{array}{l}\text { Per-capita } \\
\text { spending }\end{array}$ & $\begin{array}{l}\begin{array}{l}\text { Per-capita } \\
\text { grants }\end{array} \\
\end{array}$ & $\begin{array}{l}\text { Per-capita } \\
\text { spending }\end{array}$ \\
\hline Per-capita grants & $\begin{array}{l}1.4240 \\
(0.0556)^{* *}\end{array}$ & $\begin{array}{l}1.1356 \\
(0.0573)^{* *}\end{array}$ & & $\begin{array}{l}0.0885 \\
(0.4026)\end{array}$ & & $\begin{array}{l}-0.3362 \\
(0.5265)\end{array}$ \\
\hline Per-capita income & $\begin{array}{l}0.0010 \\
(0.0018)\end{array}$ & $\begin{array}{l}0.0086 \\
(0.0011)^{* *}\end{array}$ & $\begin{array}{l}-0.0003 \\
(0.0008)\end{array}$ & $\begin{array}{l}0.0086 \\
(0.0013) * *\end{array}$ & $\begin{array}{l}0.0000 \\
(0.0007)\end{array}$ & $\begin{array}{l}0.0086 \\
(0.0014)^{* *}\end{array}$ \\
\hline Population & & $\begin{array}{l}-0.5242 \\
(2.8966)\end{array}$ & $\begin{array}{l}-1.9496 \\
(1.9750)\end{array}$ & $\begin{array}{l}-3.1868 \\
(3.7048)\end{array}$ & $\begin{array}{l}-2.2199 \\
(1.8883)\end{array}$ & $\begin{array}{l}-4.2668 \\
(4.1657)\end{array}$ \\
\hline $\begin{array}{l}\text { Drivers per } \\
\text { capita }\end{array}$ & & $\begin{array}{l}33.0039 \\
(46.8916)\end{array}$ & $\begin{array}{l}-118.6721 \\
(32.3106)^{* *}\end{array}$ & $\begin{array}{l}-71.1619 \\
(69.8983)\end{array}$ & $\begin{array}{l}-110.3547 \\
(30.7697)^{* *}\end{array}$ & $\begin{array}{l}-113.4145 \\
(82.2872)\end{array}$ \\
\hline $\begin{array}{l}\text { Vehicles per } \\
\text { capita }\end{array}$ & & $\begin{array}{l}-57.1407 \\
(28.1232)^{* *}\end{array}$ & \begin{tabular}{|l}
34.6695 \\
$(19.4338)^{*}$
\end{tabular} & \begin{tabular}{|l}
-28.0803 \\
$(36.3195)$ \\
\end{tabular} & \begin{tabular}{|l|}
37.7705 \\
$(18.4674)^{* *}$ \\
\end{tabular} & $\begin{array}{l}-16.2926 \\
(40.9802) \\
\end{array}$ \\
\hline $\begin{array}{l}\text { Governor } \\
\text { Democrat }\end{array}$ & & \begin{tabular}{|l|}
7.0580 \\
$(2.8854)^{* *}$ \\
\end{tabular} & \begin{tabular}{|l}
-0.4544 \\
$(1.9762)$ \\
\end{tabular} & $\begin{array}{l}6.2229 \\
(3.5653)^{*} \\
\end{array}$ & \begin{tabular}{|l|}
-0.8675 \\
$(1.8842)$ \\
\end{tabular} & $\begin{array}{l}5.8842 \\
(3.9563) \\
\end{array}$ \\
\hline $\begin{array}{l}\text { State House } \\
\text { Democrats }\end{array}$ & & $\begin{array}{l}-0.3388 \\
(22.9306)\end{array}$ & $\begin{array}{l}-18.6704 \\
(16.0472)\end{array}$ & $\begin{array}{l}-19.7105 \\
(29.1596)\end{array}$ & \begin{tabular}{|l}
-19.6235 \\
$(15.1197)$ \\
\end{tabular} & $\begin{array}{l}-27.5682 \\
(32.7177) \\
\end{array}$ \\
\hline $\begin{array}{l}\text { State Senate } \\
\text { Democrats }\end{array}$ & & $\begin{array}{c}21.8783 \\
(18.6561) \\
\end{array}$ & $\begin{array}{l}12.4096 \\
(13.4121) \\
\end{array}$ & $\begin{array}{l}34.8593 \\
(23.4813) \\
\end{array}$ & $\begin{array}{l}16.0146 \\
(12.4727) \\
\end{array}$ & $\begin{array}{l}40.1248 \\
(26.2450) \\
\end{array}$ \\
\hline $\begin{array}{l}\text { U.S. House trans. } \\
\text { cmte. }\end{array}$ & & & $\begin{array}{l}-3.7836 \\
(8.9290) \\
\end{array}$ & & $\begin{array}{l}-5.0016 \\
(5.9840) \\
\end{array}$ & \\
\hline $\begin{array}{l}\text { U.S. House maj. } \\
\text { Party }\end{array}$ & & & \begin{tabular}{|l}
-7.5445 \\
$(6.2002)$ \\
\end{tabular} & & $\begin{array}{l}-15.7002 \\
(4.3844)^{* *} \\
\end{array}$ & \\
\hline U.S. House tenure & & & $\begin{array}{l}-1.2141 \\
(0.4101)^{* *} \\
\end{array}$ & & $\begin{array}{l}-0.9502 \\
(0.3483)^{* *} \\
\end{array}$ & \\
\hline $\begin{array}{l}\text { U.S. Senate trans. } \\
\text { cmte. }\end{array}$ & & & $\begin{array}{l}1.3875 \\
(6.0137) \\
\end{array}$ & & $\begin{array}{l}0.5094 \\
(4.0105)\end{array}$ & \\
\hline $\begin{array}{l}\text { U.S. Senate maj. } \\
\text { party }\end{array}$ & & & \begin{tabular}{|l|}
3.8437 \\
$(2.7851)$ \\
\end{tabular} & & $\begin{array}{l}.6528 \\
(1.9752) \\
\end{array}$ & \\
\hline U.S. Senate tenure & & & $\begin{array}{l}1.0850 \\
(0.2828)^{* *} \\
\end{array}$ & & $\begin{array}{l}0.8756 \\
(0.2700)^{* *} \\
\end{array}$ & \\
\hline Observations & 703 & 703 & 703 & 703 & 703 & 703 \\
\hline R-squared & 0.7092 & 0.9149 & 0.8908 & & & \\
\hline state fixed effects & no & yes & yes & yes & yes & yes \\
\hline $\begin{array}{l}\text { equivalence test } p \text { - } \\
\text { value }\left[\mathrm{H}_{0}: \beta_{1}=\beta_{2}\right]\end{array}$ & 0.000 & 0.000 & & 0.843 & & 0.513 \\
\hline $\begin{array}{l}\text { fiscal illusion test } \\
p \text {-value }\left[H_{0}: \beta_{1}=1\right]\end{array}$ & 0.000 & 0.018 & & 0.024 & & 0.011 \\
\hline $\begin{array}{l}\text { over identification } \\
\text { test p-value }\end{array}$ & & & & 0.224 & & 0.300 \\
\hline $\begin{array}{l}\text { instrument F-test } \\
\text { (p-value) }\end{array}$ & & & \begin{tabular}{|l}
3.40 \\
$(0.003)$ \\
\end{tabular} & & \begin{tabular}{|l|}
3.16 \\
$(0.004)$ \\
\end{tabular} & \\
\hline
\end{tabular}


Table 5

Alternative instrument sets, selected coefficients

Census Bureau Survey of Governments data

(** denotes $5 \%$ significance, * denotes $10 \%$ significance)

\begin{tabular}{|c|c|c|c|c|c|c|}
\hline & (1) & (2) & (3) & $(4)$ & (5) & (6) \\
\hline & $2 \mathrm{SLS}$ & LIML & $2 \mathrm{SLS}$ & LIML & 2SLS & LIML \\
\hline \multicolumn{7}{|l|}{$\begin{array}{l}\text { First-stage } \\
\text { coefficients }\end{array}$} \\
\hline $\begin{array}{l}\text { U.S. Senate trans. } \\
\text { cmte. }\end{array}$ & $\begin{array}{l}10.6352 \\
(6.0975)^{*}\end{array}$ & $\begin{array}{l}12.7327 \\
(5.0354)^{* *}\end{array}$ & & & $\begin{array}{l}9.5289 \\
(6.0703)\end{array}$ & $\begin{array}{l}12.3158 \\
(5.0672)^{* *}\end{array}$ \\
\hline $\begin{array}{l}\text { U.S. Senate maj. } \\
\text { party }\end{array}$ & $\begin{array}{c}0.9128 \\
(2.8520)\end{array}$ & $\begin{array}{l}1.8432 \\
(2.1941)\end{array}$ & $\begin{array}{l}1.0720 \\
(2.8551)\end{array}$ & $\begin{array}{l}1.9055 \\
(2.5725)\end{array}$ & & \\
\hline U.S. Senate tenure & $\begin{array}{l}0.6873 \\
(0.2807)^{* *}\end{array}$ & $\begin{array}{l}0.5615 \\
(0.2696)^{* *}\end{array}$ & $\begin{array}{l}0.6940 \\
(0.2811)^{* *}\end{array}$ & $\begin{array}{l}0.6815 \\
(0.2759)^{* *}\end{array}$ & $\begin{array}{l}0.6618 \\
(0.2766)^{* *}\end{array}$ & $\begin{array}{l}0.5885 \\
(0.2492)^{* *}\end{array}$ \\
\hline $\begin{array}{l}\text { U.S. Senate cmte. } \\
\text { chair }\end{array}$ & & & & & $\begin{array}{l}13.1704 \\
(4.5912)^{* *}\end{array}$ & $\begin{array}{l}12.4634 \\
(4.1906)^{* *}\end{array}$ \\
\hline \multicolumn{7}{|l|}{$\begin{array}{l}\text { Second-stage } \\
\text { coefficients }\end{array}$} \\
\hline Per-capita grants & $\begin{array}{c}0.0684 \\
(0.5599)\end{array}$ & $\begin{array}{l}-0.0858 \\
(0.6114)\end{array}$ & $\begin{array}{l}0.4378 \\
(0.6183)\end{array}$ & $\begin{array}{l}0.3768 \\
(0.6359)\end{array}$ & $\begin{array}{l}0.2141 \\
(0.3912)\end{array}$ & $\begin{array}{l}0.1577 \\
(0.3956)\end{array}$ \\
\hline Per-capita income & $\begin{array}{l}0.0100 \\
(0.0013)^{* *} \\
\end{array}$ & $\begin{array}{l}0.0101 \\
(0.0013)^{* *} \\
\end{array}$ & $\begin{array}{l}0.0098 \\
(0.0012)^{* *}\end{array}$ & $\begin{array}{l}0.0098 \\
(0.0012)^{* *}\end{array}$ & $\begin{array}{l}0.0099 \\
(0.0012)^{* *}\end{array}$ & $\begin{array}{l}0.0100 \\
(0.0012)^{* *}\end{array}$ \\
\hline Observations & 705 & 705 & 705 & 705 & 705 & 705 \\
\hline State fixed effects & yes & yes & yes & yes & yes & Yes \\
\hline $\begin{array}{l}\text { Equivalence test } p \text { - } \\
\text { value }\left[H_{0}: \beta_{1}=\beta_{2}\right]\end{array}$ & 0.917 & 0.876 & 0.489 & 0.564 & 0.602 & 0.709 \\
\hline $\begin{array}{l}\text { fiscal illusion test } p \text { - } \\
\text { value }\left[\mathrm{H}_{0}: \beta_{1}=1\right]\end{array}$ & 0.097 & 0.076 & 0.364 & 0.327 & 0.045 & 0.033 \\
\hline $\begin{array}{l}\text { over identification } \\
\text { test p-value }\end{array}$ & 0.494 & 0.512 & 0.401 & 0.426 & 0.530 & 0.530 \\
\hline $\begin{array}{l}\text { instrument F-test (p- } \\
\text { value) }\end{array}$ & \begin{tabular}{|l|}
3.05 \\
$(0.028)$
\end{tabular} & $\begin{array}{l}3.15 \\
(0.024)\end{array}$ & \begin{tabular}{|l}
3.05 \\
$(0.048)$
\end{tabular} & \begin{tabular}{|l|}
3.27 \\
$(0.038)$
\end{tabular} & \begin{tabular}{|l|}
5.80 \\
$(0.001)$
\end{tabular} & \begin{tabular}{|l|}
6.20 \\
$(0.000)$ \\
\end{tabular} \\
\hline
\end{tabular}


Table 6

Alternative instrument sets, selected coefficients

Federal Highway Administration Highway Statistics data

(** denotes $5 \%$ significance, * denotes $10 \%$ significance)

\begin{tabular}{|c|c|c|c|c|c|c|}
\hline & (1) & (2) & (3) & $(4)$ & (5) & (6) \\
\hline & $2 S L S$ & LIML & $2 \mathrm{SLS}$ & LIML & $2 S L S$ & LIML \\
\hline \multicolumn{7}{|l|}{$\begin{array}{l}\text { First-stage } \\
\text { coefficients }\end{array}$} \\
\hline $\begin{array}{l}\text { U.S. Senate } \\
\text { trans. cmte. }\end{array}$ & $\begin{array}{c}3.3872 \\
(5.8515)\end{array}$ & $\begin{array}{l}2.9504 \\
(5.0663)\end{array}$ & & & $\begin{array}{l}2.0565 \\
(5.7964)\end{array}$ & $\begin{array}{l}2.0289 \\
(5.3539)\end{array}$ \\
\hline $\begin{array}{l}\text { U.S. Senate maj. } \\
\text { party }\end{array}$ & $\begin{array}{c}3.3812 \\
(2.7388)\end{array}$ & $\begin{array}{l}3.6892 \\
(2.3753)\end{array}$ & $\begin{array}{c}3.4319 \\
(2.7359)\end{array}$ & $\begin{array}{l}3.7234 \\
(2.3701)\end{array}$ & & \\
\hline $\begin{array}{l}\text { U.S. Senate } \\
\text { tenure }\end{array}$ & $\begin{array}{l}0.8042 \\
(0.2695)^{* *}\end{array}$ & $\begin{array}{l}0.7975 \\
(0.2568)^{* *}\end{array}$ & $\begin{array}{l}0.8063 \\
(0.2693)^{* *}\end{array}$ & $\begin{array}{l}0.7961 \\
(0.2582)^{* *}\end{array}$ & $\begin{array}{l}0.7423 \\
(0.2643)^{* *}\end{array}$ & $\begin{array}{l}0.7782 \\
(0.2447)^{* *}\end{array}$ \\
\hline $\begin{array}{l}\text { U.S. Senate cmte. } \\
\text { member }\end{array}$ & & & & & $\begin{array}{l}17.6577 \\
(4.3889)^{* *}\end{array}$ & $\begin{array}{l}17.2130 \\
(4.2250)^{* *}\end{array}$ \\
\hline \multicolumn{7}{|l|}{$\begin{array}{l}\text { Second-stage } \\
\text { coefficients }\end{array}$} \\
\hline Per-capita grants & $\begin{array}{c}0.4263 \\
(0.5146)\end{array}$ & $\begin{array}{c}0.4192 \\
(0.4974)\end{array}$ & $\begin{array}{l}0.4102 \\
(0.5257)\end{array}$ & $\begin{array}{l}0.4049 \\
(0.5072)\end{array}$ & $\begin{array}{l}0.7434 \\
(0.3080)^{* *}\end{array}$ & $\begin{array}{l}0.7369 \\
(0.2984)^{* *}\end{array}$ \\
\hline Per-capita income & $\begin{array}{l}0.0086 \\
(0.0012)^{* *}\end{array}$ & $\begin{array}{l}0.0086 \\
(0.0011)^{* *}\end{array}$ & $\begin{array}{l}0.0086 \\
(0.0012)^{* *}\end{array}$ & $\begin{array}{l}0.0086 \\
(0.0011)\end{array}$ & $\begin{array}{l}0.0086 \\
(0.0011)^{* *}\end{array}$ & $\begin{array}{l}0.0086 \\
(0.0010)^{* *}\end{array}$ \\
\hline Observations & 703 & 703 & 703 & 705 & 703 & 703 \\
\hline State fixed effects & yes & yes & yes & yes & yes & yes \\
\hline $\begin{array}{l}\text { equivalence test } p \text { - } \\
\text { value } H_{0}: \beta_{1}=\beta_{2}\end{array}$ & 0.417 & 0.409 & 0.445 & 0.435 & 0.017 & 0.015 \\
\hline $\begin{array}{l}\text { fiscal illusion test } p \text { - } \\
\text { value } H_{0}: \beta_{1}=1\end{array}$ & 0.265 & 0.243 & 0.2622 & 0.2407 & 0.405 & 0.378 \\
\hline $\begin{array}{l}\text { over identification } \\
\text { test p-value }\end{array}$ & 0.932 & 0.961 & 0.791 & 0.791 & 0.810 & 0.810 \\
\hline $\begin{array}{l}\text { instrument F-test (p- } \\
\text { value) }\end{array}$ & $\begin{array}{l}3.36 \\
(0.019)\end{array}$ & $\begin{array}{l}3.64 \\
(0.012)\end{array}$ & $\begin{array}{l}4.87 \\
(0.008)\end{array}$ & $\begin{array}{l}5.29 \\
(0.005)\end{array}$ & $\begin{array}{l}8.31 \\
(0.000)\end{array}$ & $\begin{array}{l}9.03 \\
(0.000)\end{array}$ \\
\hline
\end{tabular}




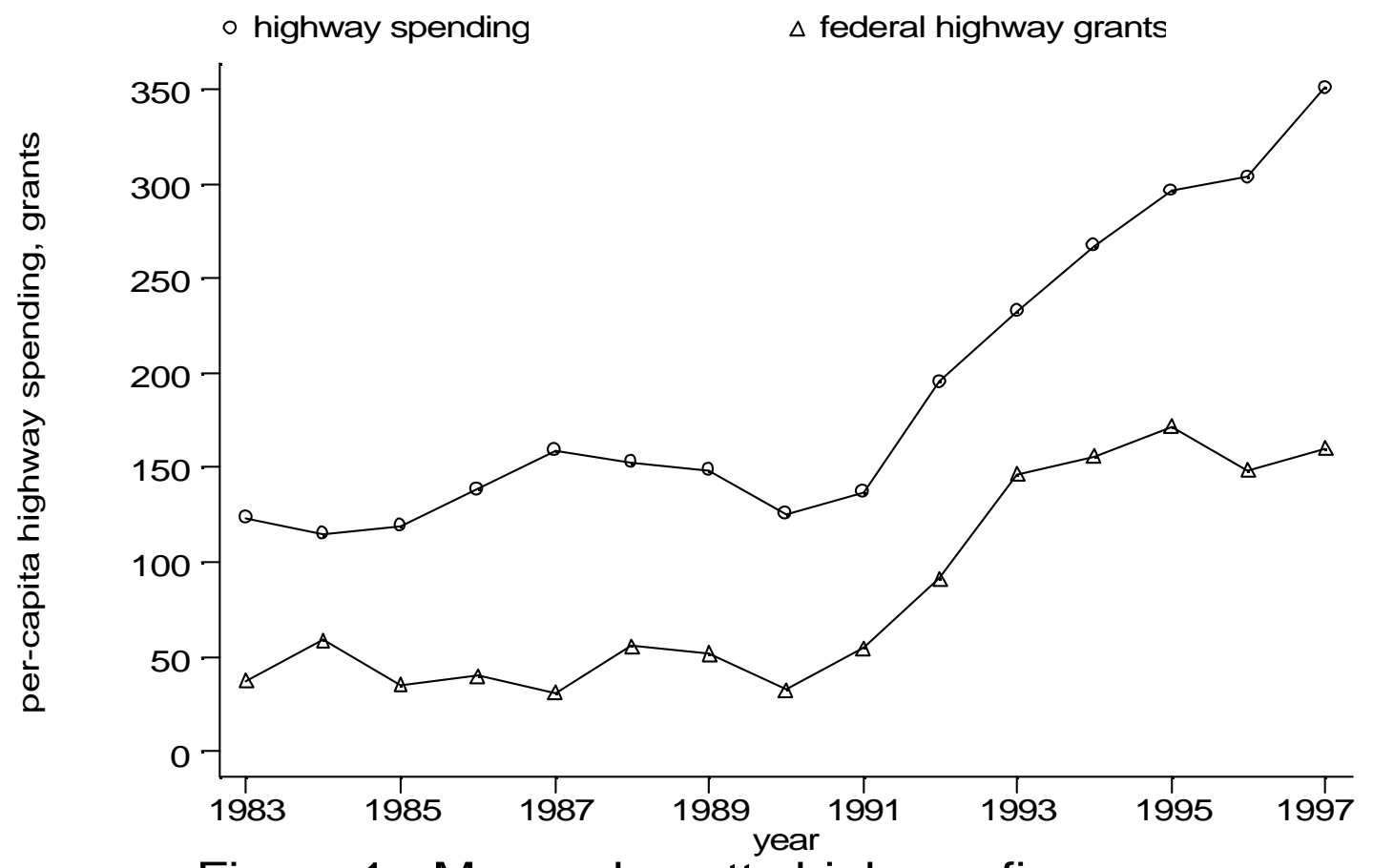

Figure 1 - Massachusetts highway finances 

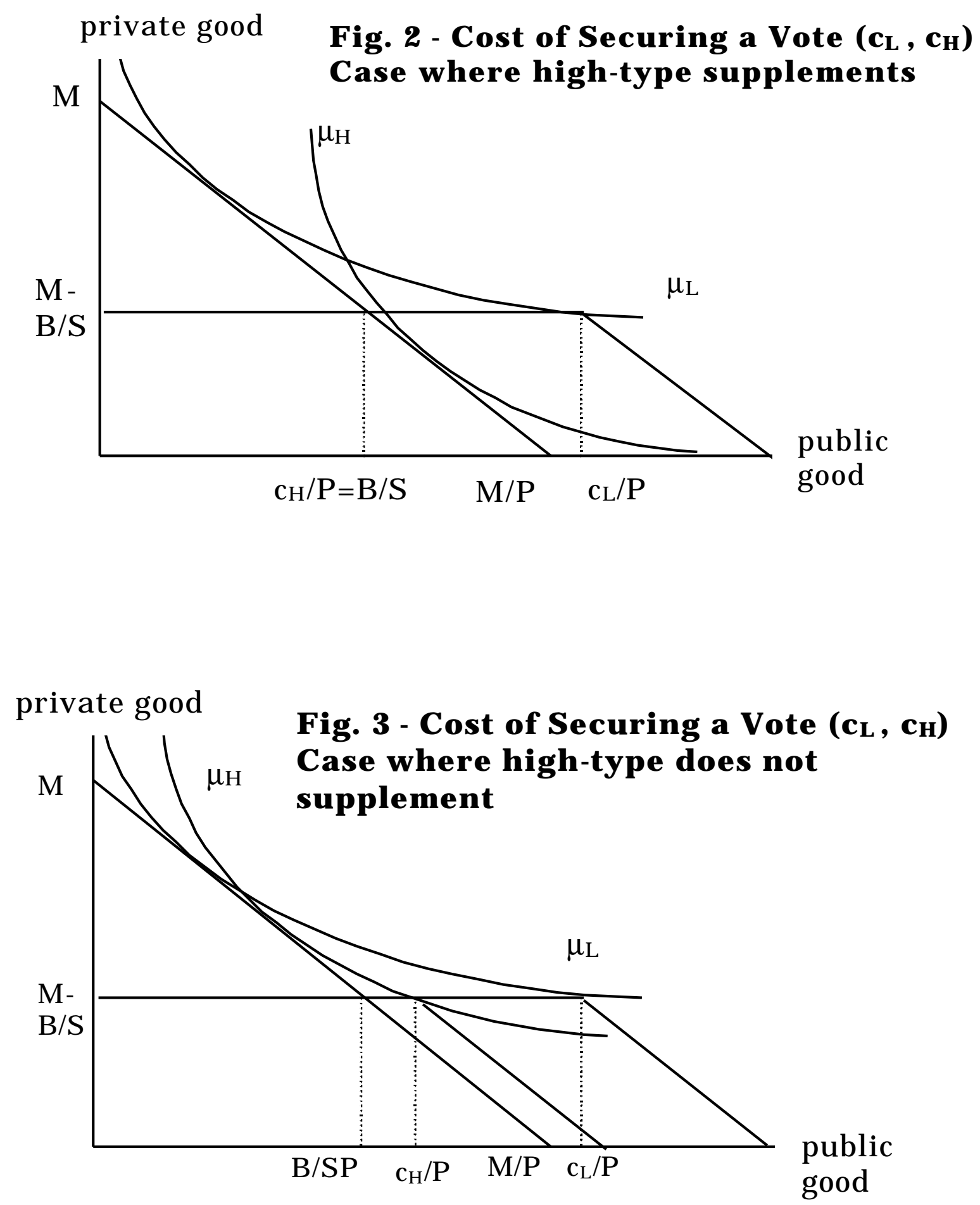


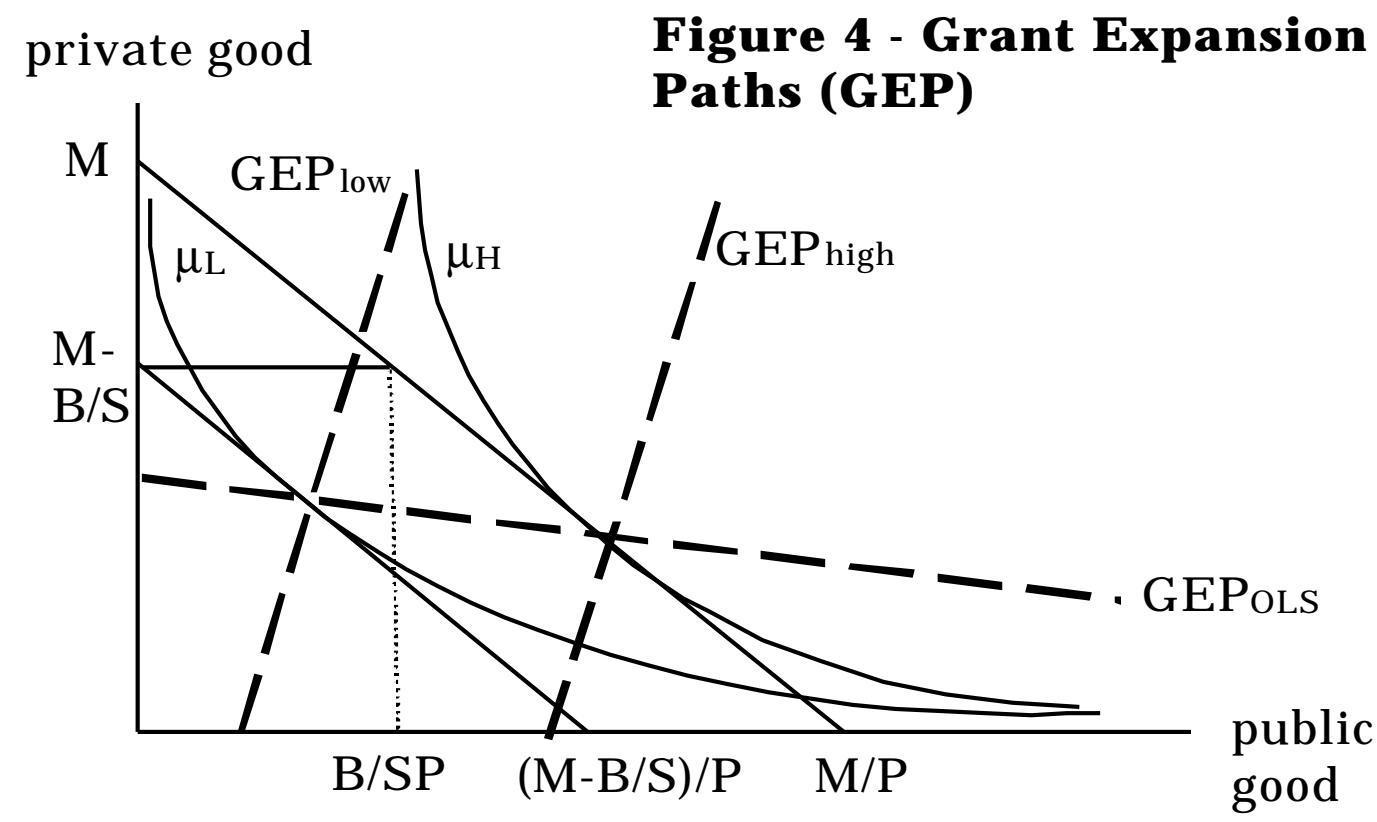




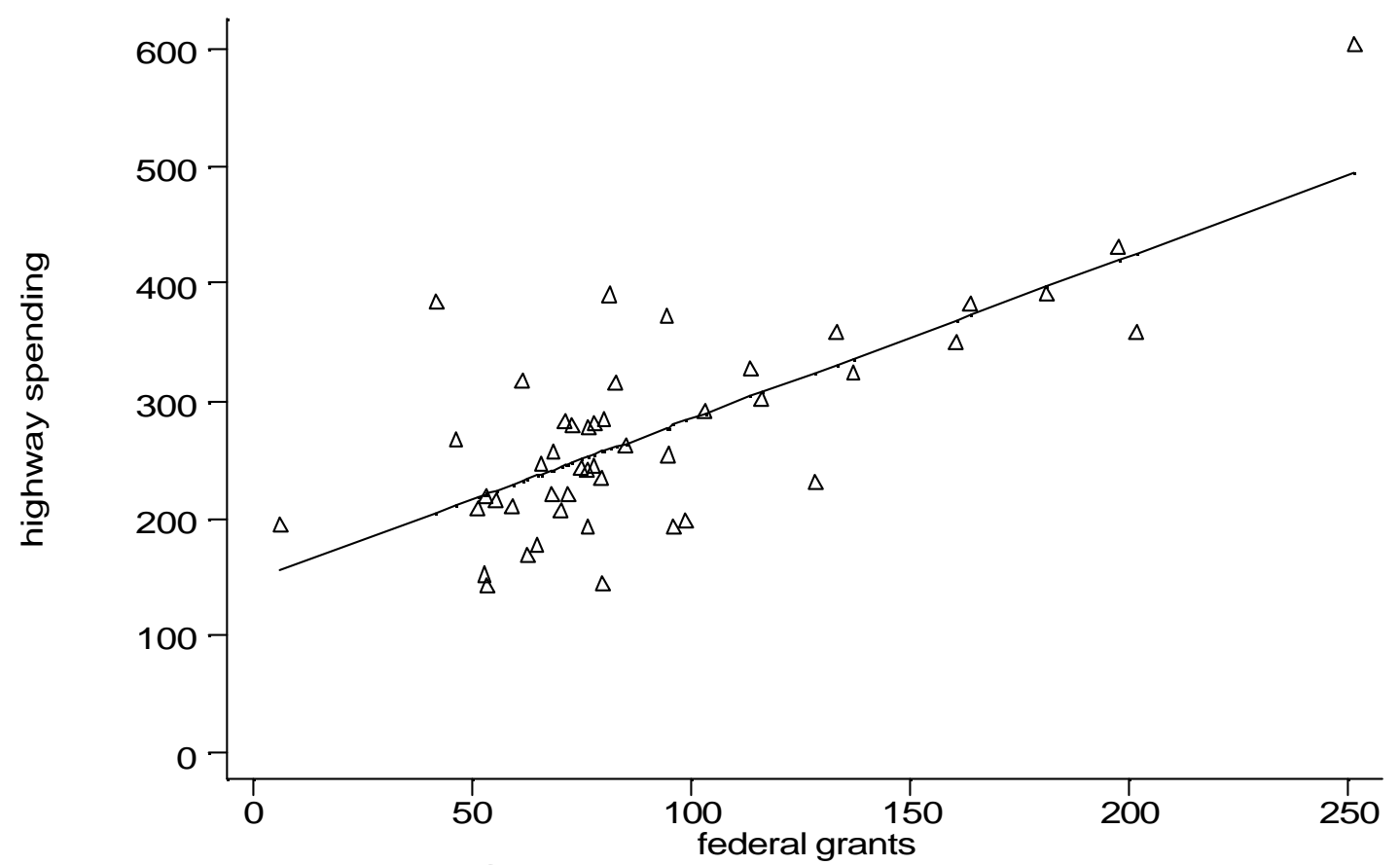

Figure 5 - Cross-sectional variation, 1997 


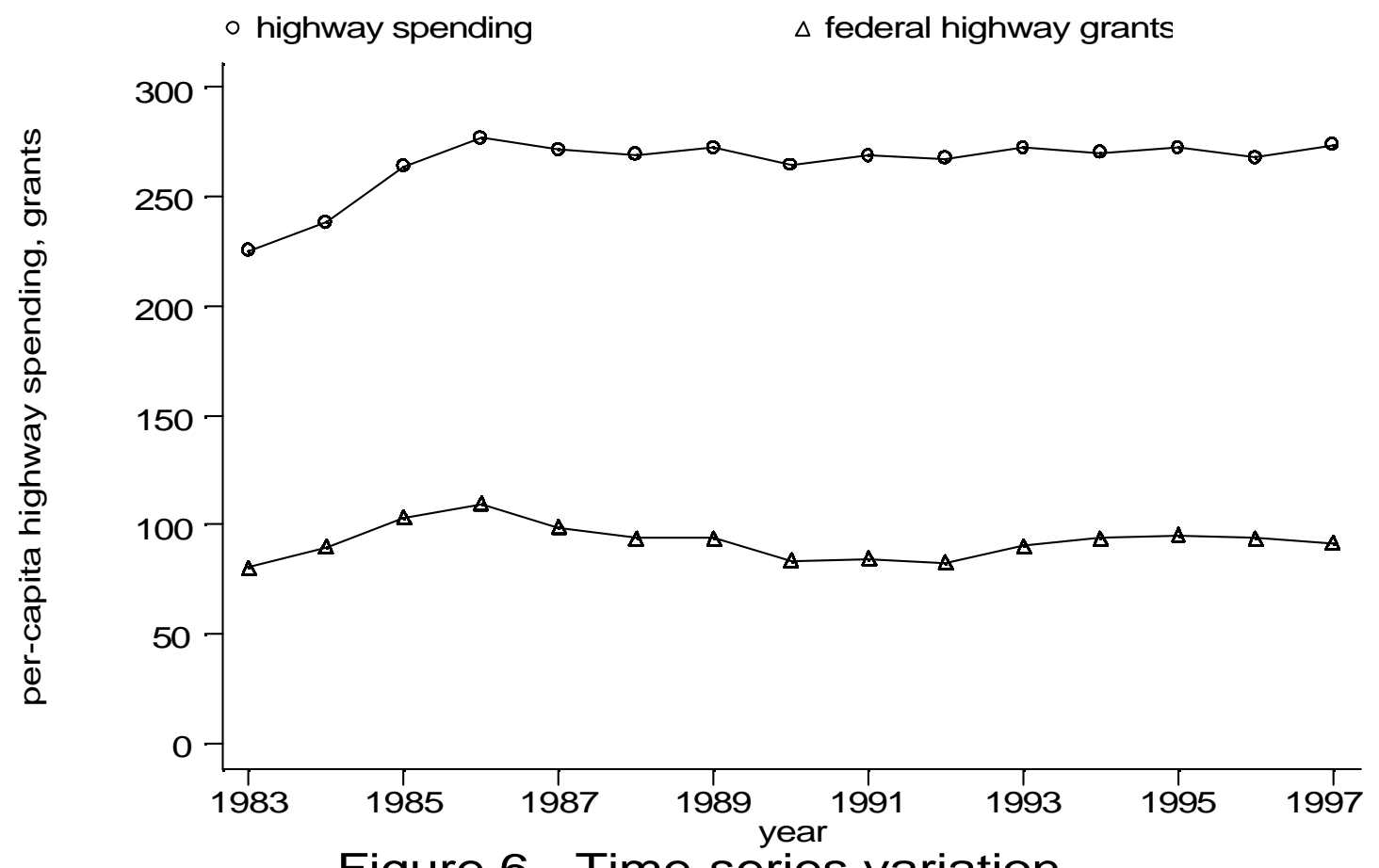

Figure 6 - Time-series variation 


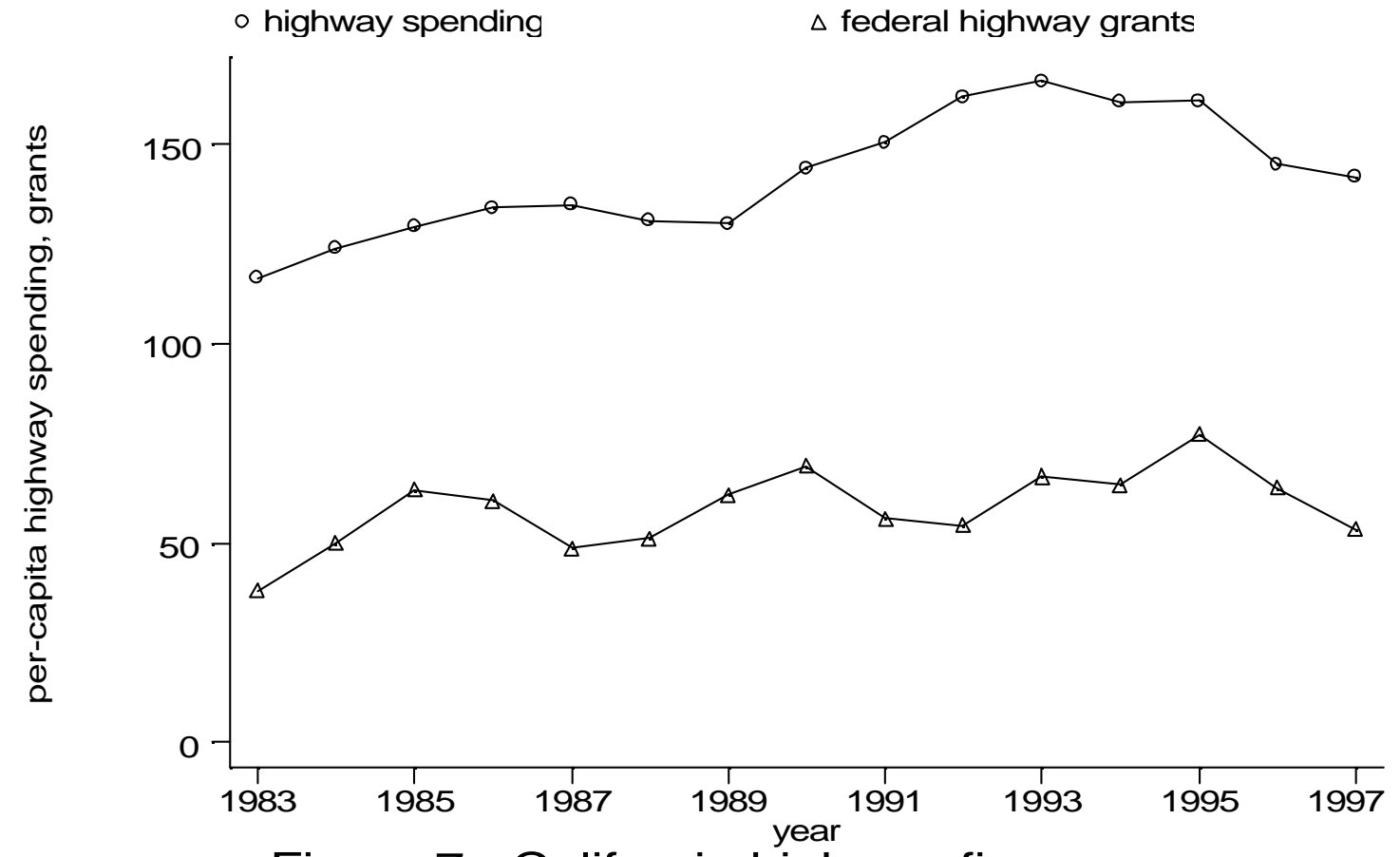

Figure 7 - California highway finances 


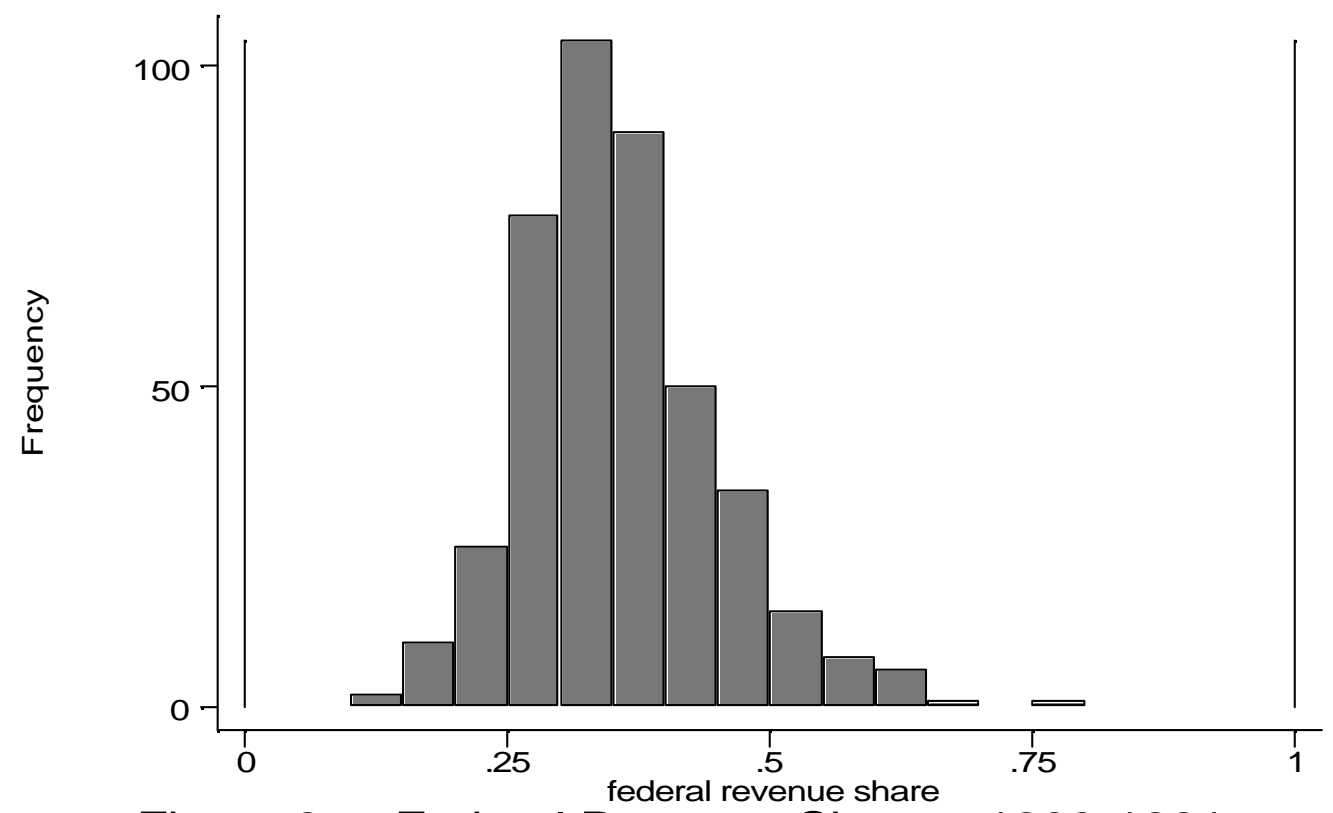

Figure 8a - Federal Revenue Shares, 1983-1991

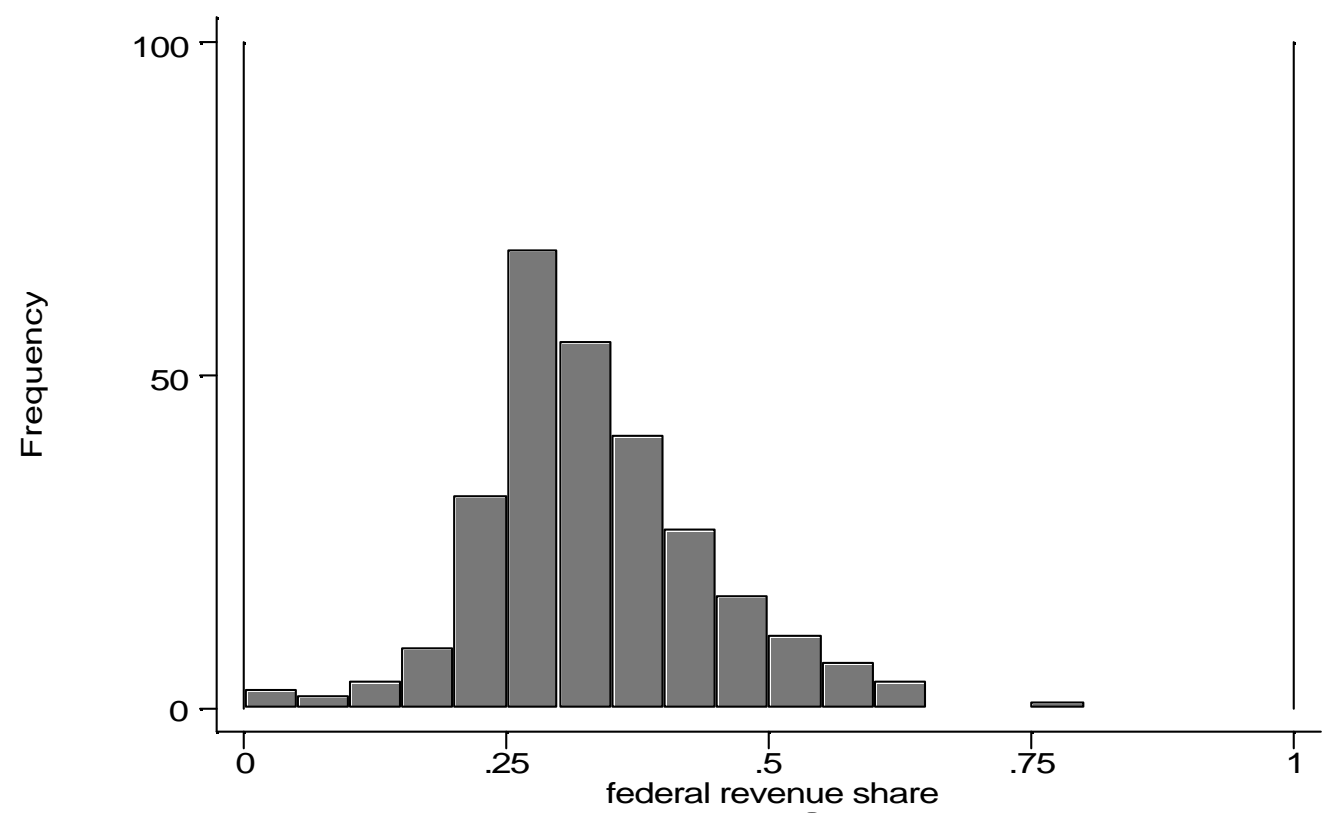

Figure 8b - Federal Revenue Shares, 1992-1997 